RESEARCH SERIES

NUMBER 107 July 2020

\section{INCOME ADEQUACY IN RETIREMENT}

EVIDENCE FROM THE IRISH LONGITUDINAL STUDY ON AGEING (TILDA)

KEELAN BEIRNE, ANNE NOLAN AND BARRA ROANTREE

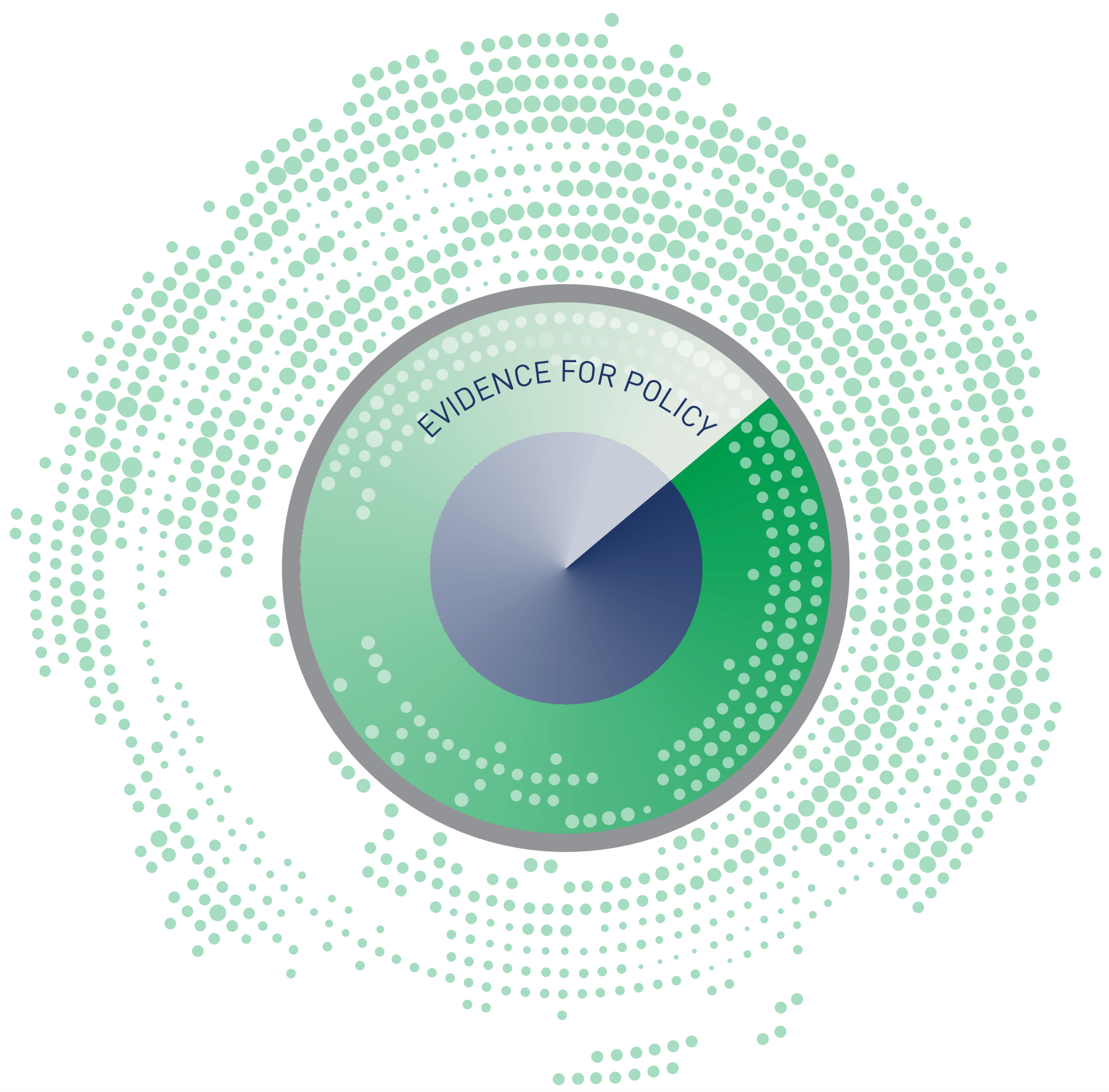




\section{INCOME ADEQUACY IN RETIREMENT: EVIDENCE FROM THE IRISH LONGITUDINAL STUDY ON AGEING (TILDA)}

Keelan Beirne

Anne Nolan

Barra Roantree

July 2020

\section{RESEARCH SERIES}

\section{NUMBER 107}

Available to download from www.esri.ie

The Economic and Social Research Institute

Whitaker Square, Sir John Rogerson's Quay, Dublin 2

ISBN 978-0-7070-0530-0

DOI https://doi.org/10.26504/rs107

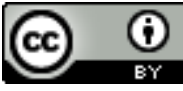

This Open Access work is licensed under a Creative Commons Attribution 4.0 International License (https://creativecommons.org/licenses/by/4.0/), which permits unrestricted use, distribution, and reproduction in any medium, provided the original work is properly credited. 


\section{ABOUT THE ESRI}

The mission of the Economic and Social Research Institute is to advance evidencebased policymaking that supports economic sustainability and social progress in Ireland. ESRI researchers apply the highest standards of academic excellence to challenges facing policymakers, focusing on 12 areas of critical importance to 21st Century Ireland.

The Institute was founded in 1960 by a group of senior civil servants led by Dr T.K. Whitaker, who identified the need for independent and in-depth research analysis to provide a robust evidence base for policymaking in Ireland.

Since then, the Institute has remained committed to independent research and its work is free of any expressed ideology or political position. The Institute publishes all research reaching the appropriate academic standard, irrespective of its findings or who funds the research.

The quality of its research output is guaranteed by a rigorous peer review process. ESRI researchers are experts in their fields and are committed to producing work that meets the highest academic standards and practices.

The work of the Institute is disseminated widely in books, journal articles and reports. ESRI publications are available to download, free of charge, from its website. Additionally, ESRI staff communicate research findings at regular conferences and seminars.

The ESRI is a company limited by guarantee, answerable to its members and governed by a Council, comprising 14 members who represent a cross-section of ESRI members from academia, civil services, state agencies, businesses and civil society. The Institute receives an annual grant-in-aid from the Department of Public Expenditure and Reform to support the scientific and public interest elements of the Institute's activities; the grant accounted for an average of 30 per cent of the Institute's income over the lifetime of the last Research Strategy. The remaining funding comes from research programmes supported by government departments and agencies, public bodies and competitive research programmes.

Further information is available at www.esri.ie. 


\section{THE AUTHORS}

Anne Nolan is an Associate Research Professor at the Economic and Social Research Institute (ESRI) and an Adjunct Professor at Trinity College Dublin (TCD). Barra Roantree is a Research Officer at the ESRI and an Adjunct Assistant Professor at TCD. Keelan Beirne was a Research Assistant at the ESRI.

\section{ACKNOWLEDGEMENTS}

We are grateful to the Irish Longitudinal Study of Ageing (TILDA) for granting us access to the Research Microdata File. This work was carried out with funding from the ESRI's Tax, Welfare and Pensions Research Programme (supported by the Department of Public Expenditure and Reform, the Department of Employment Affairs and Social Protection, the Department of Health, the Department of Children and Youth Affairs, and the Department of Finance), which is gratefully acknowledged. We thank our former colleague Sanna Nivakoski who assisted with coding in the initial stages of the project. We are grateful to Karina Doorley, Roshin Sen, Alan Flynn and Margaret Mulhall for their helpful suggestions, as well as to three anonymous referees for their comments on an earlier draft of this paper and David Quin for his assistance in copyediting this report. All views, errors and omissions remain the sole responsibility of the authors.

This report has been accepted for publication by the Institute, which does not itself take institutional policy positions. All ESRI Research Series reports are peer reviewed prior to publication. The author(s) are solely responsible for the content and the views expressed. 



\section{TABLE OF CONTENTS}

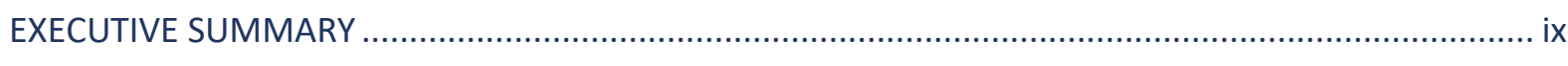

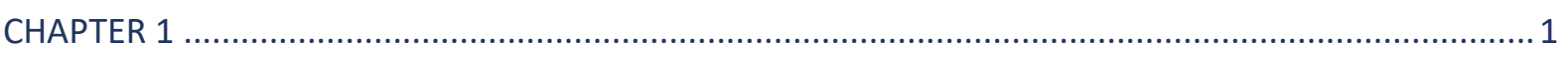

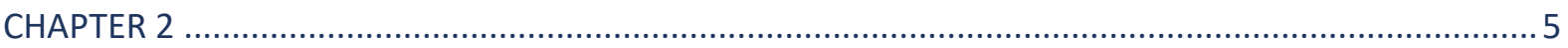

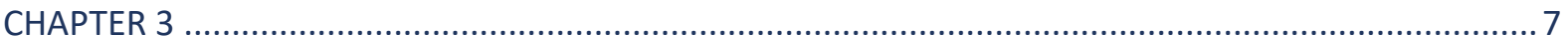

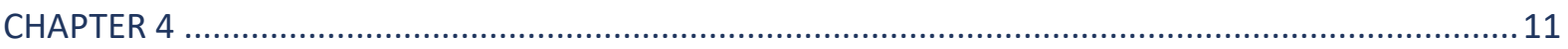

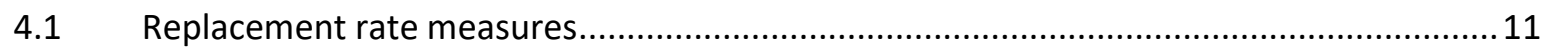

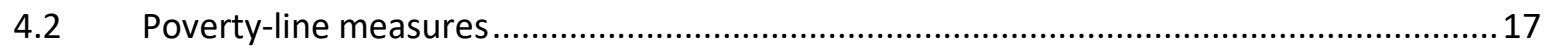

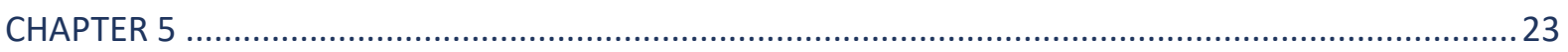

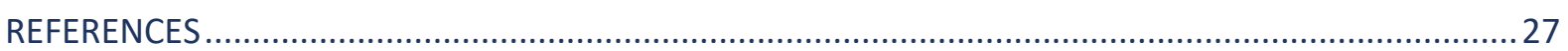

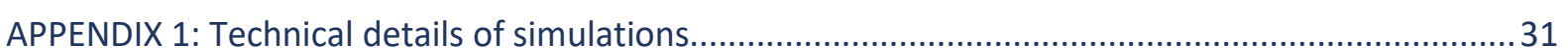

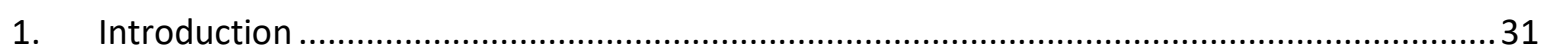

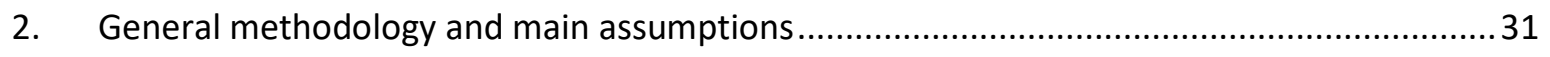

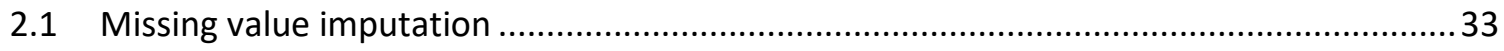

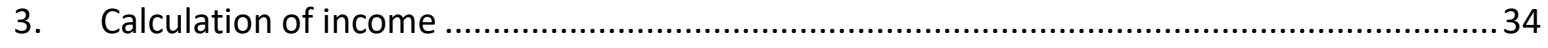

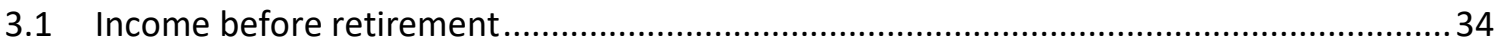

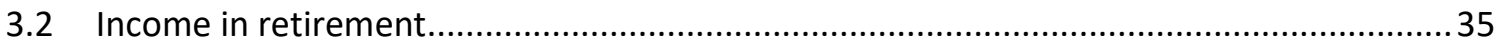

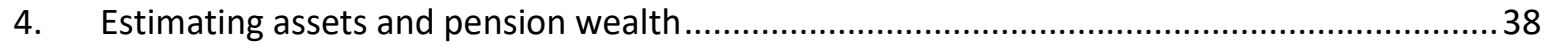

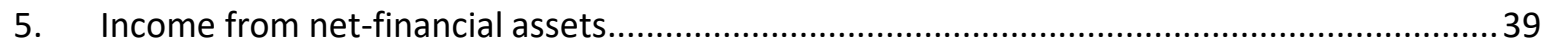

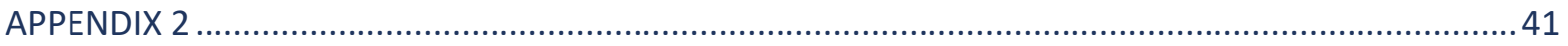





\section{LIST OF TABLES}

Table 1 Replacement rate measures of income adequacy ….......................................................

Table 2 Poverty line measures of income adequacy..................................................................... xi

Table 3.1 Simulated distribution of retirement income, by definition of income..........................10

Table 4.1 Replacement rate measures of income adequacy.........................................................13

Table 4.2 Logistic Regression of replacement rate income adequacy benchmark ........................15

Table 4.3 Poverty line measures of income adequacy ............................................................. 17

Table 4.4 Weekly 'Minimum Essential Standard of Living' thresholds, 2019 ................................19

Table 4.5 Logistic Regression of Poverty-line income adequacy benchmark ................................20

Table 4.6 Correlation between adequacy benchmarks (narrow Income definition) .....................21

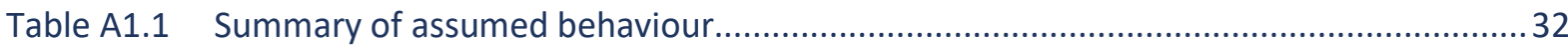

Table A1.2 Summary of assumptions of growth rates of economic variables..................................33

Table A1.3 Simulated state contributory pension entitlements under different schemes (in 2019)

for TILDA Cohort

Table A2.1 Logistic regression of replacement rate income adequacy benchmark (including annuitised value of net financial assets)

Table A2.2 Logistic regression of replacement rate income adequacy benchmark (including annuitised value of net financial assets plus half primary residence)

Table A2.3 Logistic regression of poverty-line rate income adequacy benchmark (including annuitised value of net financial assets).

Table A2.4 Logistic regression of poverty-line income adequacy benchmark (including annuitised value of net financial assets plus half value of primary residence)

\section{LIST OF FIGURES}

Figure 3.1 Simulated distribution of retirement income, by definition of income...........................

Figure 4.1 Cumulative distribution of replacement rates, by income measure ….........................14

Figure 4.2 Share of individuals below poverty line, by definition of poverty line ........................... 18 



\section{ABBREVIATIONS}

$\begin{array}{ll}\text { CAT } & \text { Capital Acquisitions Tax } \\ \text { CBI } & \text { Central Bank of Ireland } \\ \text { CGT } & \text { Capital Gains Tax } \\ \text { CSO } & \text { Central Statistics Office } \\ \text { DB } & \text { Defined Benefit } \\ \text { DC } & \text { Defined Contribution } \\ \text { ESRI } & \text { Economic and Social Research Institute } \\ \text { MESL } & \text { Minimum Essential Standard of Living } \\ \text { PRSI } & \text { Pay-Related Social Insurance } \\ \text { SPA } & \text { State Pension Age } \\ \text { TCA } & \text { Total Contributions Approach } \\ \text { TILDA } & \text { The Irish Longitudinal Study on Ageing } \\ \text { USC } & \text { Universal Social Charge }\end{array}$




\section{EXECUTIVE SUMMARY}

A key area of policy concern is to what extent those approaching the state pension age (SPA) will have adequate resources in retirement. While the current rate of income poverty among the older population is lower than for other groups (particularly children), concerns over the adequacy of retirement income in Ireland are widespread. In this report, we use data from the Irish Longitudinal Study on Ageing (TILDA) to assess the extent to which a cohort of individuals born between 1955 and 1960, who will reach the SPA of 67 over the period 2022-2027, will have an adequate level of income in retirement. We use information on their incomes, work history and wealth holdings, recorded at the first wave of TILDA data collection in 2010, to simulate forward these adults' likely incomes in retirement, from both private and public sources.

One commonly used measure of retirement income adequacy is the income replacement rate, defined as the ratio of post-retirement income (from pensions, annuitised wealth holdings, etc) to pre-retirement income. Replacement rate measures of retirement income adequacy have been to the forefront of government policy in Ireland in recent decades. In this report we assess the adequacy of retirement income using three replacement rate benchmarks:

- $\quad<50$ per cent of pre-retirement earnings;

- <67 per cent of pre-retirement household disposable income; and

- $<80$ per cent of pre-retirement household disposable income.

An alternative approach assesses the adequacy of retirement income by determining whether it is sufficient to meet basic needs (i.e. having a high-enough income to be able to purchase necessities such as housing, food and clothing). This is assessed in terms of whether retirement resources are below some benchmark of income poverty. Three poverty-line benchmarks are assessed in this report:

- <60 per cent of median household disposable income (the current at-risk-of-poverty threshold);

- $<50$ per cent of median household disposable income; and

- <the Minimum Essential Standard of Living (MESL) calculated by the Vincentian Partnership for Social Justice (2019).

We also consider successively broader definitions of what constitutes income in retirement, starting with a narrow definition that includes state and supplementary pension income only. The broad measure incorporates the annuitised value of net financial assets, while the broadest measure includes half the annuitised value of owner-occupied housing wealth. 
Focusing first on the replacement rate measures, the analysis shows that, on the narrowest definition of income, just over a fifth of those approaching the SPA will replace less than half of their pre-retirement earnings (see Table 1). This falls to 16.7 per cent when one includes the annuitised value of net financial assets (excluding primary residences) in the definition of income, and 12 per cent when half the annuitised value of primary residences is added. Assessing retirement income against pre-retirement household disposable income rather than preretirement earnings shows instead that over half of those approaching the SPA will replace less than 67 per cent of their pre-retirement disposable income, while more than 6 in 10 will replace less than 80 per cent. Again, these shares fall substantially - to 41.9 per cent and 50.1 per cent respectively - when one includes the annuitised value of net financial assets, and further still - to 36.1 per cent and 44.6 per cent - when half the annuitised value of primary residences is added. Those more at risk of having lower replacement rates in retirement include women, people with higher levels of education and those living alone.

\begin{tabular}{l|c|c|c|}
\hline & (1) & (2) & (3) \\
\hline Share with income in retirement that is: & $<50 \%$ earnings & $<67 \%$ income & $<80 \%$ income \\
\hline Measure of income in retirement: & & & 0.633 \\
\hline Narrow & 0.230 & 0.545 & 0.501 \\
\hline Plus annuitised value of net-financial assets & 0.167 & 0.419 & 0.446 \\
\hline Plus half annuitised value of primary residences & 0.120 & 0.361 & \\
\hline
\end{tabular}

Source: Authors' calculations using data from the Irish Longitudinal Study of Ageing (TILDA).

Note: Replacement rates calculated at an individual level comparing equivalised household disposable income in retirement to equivalised household gross earnings before retirement (column 1 ) and equivalised disposable income before retirement (columns 2 and 3 ).

When retirement income is assessed against the current at-risk-of-poverty benchmark, 24.4 per cent of those approaching the SPA are likely to have inadequate income in retirement, using the narrowest definition of income (see Table 2). However, as with replacement rate measures of adequacy, this falls markedly when one includes the annuitised value of net financial assets and half the annuitised value of primary residences - to 9.2 and 5.4 per cent respectively. The share of individuals classified as having inadequate income is also far lower if we use an alternative benchmark that aligns with the OECD definition of the poverty rate. On this measure - having income below 50 per cent rather than 60 per cent of the national median - only 7.1 per cent of individuals would have an inadequate level of retirement income using the narrowest definition and only 2.1 per cent using the broadest definition. Finally, assessing retirement income against the MESL benchmark shows that 27.5 per cent of the cohort would fall below this benchmark using the narrowest definition of income. Again, this share falls substantially - to 16.8 per cent and 7.5 per cent - when one includes the annuitised value of net financial assets and half the annuitised value of primary residences respectively. In contrast to the replacement rate results, those with higher levels 
of education are less likely to be assessed as having an inadequate income in retirement using the poverty-line benchmarks. However, those living alone emerge once again as a group with a higher probability of having inadequate retirement incomes.

\begin{tabular}{|c|c|c|c|}
\hline & (1) & (2) & (3) \\
\hline Share with income in retirement that is: & $<60 \%$ median & $<50 \%$ median & $<M E S L$ \\
\hline \multicolumn{4}{|l|}{ Measure of income in retirement: } \\
\hline Narrow & 0.244 & 0.071 & 0.275 \\
\hline Plus annuitised value of net-financial assets & 0.092 & 0.030 & 0.168 \\
\hline Plus half annuitised value of primary residences & 0.054 & 0.021 & 0.075 \\
\hline $\begin{array}{l}\text { Authors' calculations using data from the Irish Longi } \\
\text { Median equivalised income for } 60 \text { and } 50 \text { per cen } \\
\text { Conditions, uprated by forecast wage growth. MESL } \\
\text { for pensioner households, uprated by forecast wage }\end{array}$ & $\begin{array}{l}\text { inal Study of Agein } \\
\text { overty lines taken } \\
\text { ulated by the Vince } \\
\text { owth. }\end{array}$ & $\begin{array}{l}\text { A). } \\
2017 \text { Survey of Inc } \\
\text { Partnership for Soci }\end{array}$ & $\begin{array}{l}\text { iving } \\
\text { 019) }\end{array}$ \\
\hline
\end{tabular}

A number of implications arise from this analysis. First, assessments of adequacy are very sensitive to the benchmark used. Even small changes in the benchmark can result in large changes in the proportion assessed as having inadequate resources in retirement. For example, moving from a poverty-line benchmark of 60 per cent of median household disposable income (the current at-risk-of-poverty threshold) to a 50 per cent of median household disposable income benchmark (the OECD at-risk-of-poverty threshold) results in a sharp fall in those with inadequate levels of income in retirement (from 24.4 per cent to 7.1 per cent using the narrow definition of income). This suggests that policymakers should interpret any particular benchmark of income adequacy with caution, particularly those that relate income in retirement to the amount of pre-retirement income it replaces.

Second, across all benchmarks, broadening the definition of income in retirement to include financial assets, and further still to include half the value of owneroccupied housing wealth, substantially reduces the proportions of those who are considered at risk of having inadequate resources in retirement. While the issue of whether individuals should draw on wealth in the form of primary residences to support living standards in retirement is contentious, less so is that individuals should draw on other forms of wealth. Our results suggest that private nonpension, non-primary residence savings play an important role in individuals' preparedness for retirement. Although uncertainty over future health and longterm costs, as well as the desire to leave bequests to children, may partly explain the reticence on the part of individuals to sell these assets to fund consumption in retirement, the design of capital taxes may also influence behaviour. Currently, assets transferred at death are fully exempt from Capital Gains Tax (CGT), which incentivises individuals to hold onto these assets rather than dispose of them in retirement. Any assessment of capital taxation should therefore consider the impacts of the design of these taxes on the behaviour of retirees. 
Third, across all the benchmarks we consider, one group of people stands out as being at particular risk of having an inadequate income in retirement: those who are not married or cohabitating in the years before retirement. The Living Alone Increase, an additional payment made to recipients of both the contributory and non-contributory state pension and certain other social welfare payments) could therefore be a particularly well-targeted instrument for addressing concerns about income adequacy in retirement among those approaching the SPA.

More generally, there is a need for more explicit discussion of the inherent tradeoffs involved in meeting benchmarks of income adequacy in retirement. Policy debates often consider more saving for retirement to be unambiguously a positive thing. In many cases it may well be. However, there is - all else being equal - a trade-off between living standards in retirement and in working life. For someone who has low levels of lifetime income, more saving for retirement comes at the expense of lower living standards during working life when needs might be high, particularly in the presence of children. While this trade-off can be relaxed by redistribution within or across cohorts, requiring individuals to save more for their retirement imposes costs during working life that should be taken into account in the formulation of pension policy. 


\title{
Introduction
}

\begin{abstract}
A key area of policy concern is to what extent those approaching the state pension age (SPA) will have adequate resources in retirement. While the current rate of income poverty among the older (65+) population at 11.4 per cent is lower than for other population groups - particularly children under 18 , at 15.9 per cent (CSO, 2019a) $)^{1}$ - concerns over the adequacy of retirement income in Ireland are widespread (e.g. Government of Ireland, 2018; Mulligan et al., 2019). ${ }^{2}$
\end{abstract}

However, assessing the adequacy of income in retirement is complicated by the diversity of labour market histories, wealth holdings, future health status, and preferences regarding consumption in retirement across the population (Dudel and Schmied, 2019; Poterba, 2015). One commonly used measure of retirement income adequacy is the income replacement rate, defined as the ratio of postretirement income (from pensions, annuitised wealth holdings, etc) to preretirement income (such as earnings during the years preceding retirement, or average earnings over the working life). The theoretical framework underpinning this approach is that individuals accumulate wealth during their working lives, and then draw down this asset wealth in order to smooth their consumption over their lifetime (Knoff et al., 2016).

Such an approach underlies the setting of targets for retirement income adequacy in Ireland. For example, the most recent Pensions Roadmap 2018-2023 aims to ensure that the state pension, in combination with supplementary pensions, replaces a sufficient proportion (between 50 and 60 per cent) ${ }^{3}$ of an individual's pre-retirement earnings so as to enable them to maintain a reasonable standard of living after retirement (Government of Ireland, 2018). Furthermore, the Government has indicated that it intends to index the maximum level of the contributory state pension to 34 per cent of average earnings, though it has yet to announce the formal mechanism that will ensure this target is met (ibid).

To date, research in an Irish context has also focused on replacement rates in assessing the adequacy of retirement income (Bercholz et al., 2019; Nivakoski,

\footnotetext{
${ }^{1}$ Rates of material deprivation (8.2 per cent) and consistent poverty (1.7 per cent) among the older population are also considerably lower than among other age groups. For example, rates of material deprivation among children were 19.7 per cent in 2018, and the rate of consistent poverty was 7.7 per cent (CSO, 2019a).

${ }^{2}$ The 'at risk of poverty' rate is generally defined as having an equivalised disposable income below 60 per cent of the median equivalised income for the population.

${ }^{3}$ Individuals may need less than their full pre-retirement income to maintain their level of consumption in retirement because they incur fewer work-related expenses, can devote more time to home production, generally pay less in taxes, no longer need to save for retirement, have fewer dependents, and are less likely to be servicing mortgage and other types of debt (Crawford and O'Dea, 2012; Dudel and Schmied, 2019; Munnell et al., 2015). On the other hand, uncertainty over future health and long-term care costs may necessitate a higher replacement rate.
} 
2014; Nivakoski and Barrett, 2019). Using data from the Irish Longitudinal Study on Ageing (TILDA), Nivakoski (2014) and Nivakoski and Barrett (2019) found that income replacement rates were highest for women and those at the bottom of the earnings distribution, more reflecting the lower earnings of these groups immediately prior to retirement than high levels of resources available in retirement. Bercholz et al. (2019) calculated (contributory) state pension income replacement rates for those in the potential target group for auto-enrolment ${ }^{4}$ (aged 23-60, earning over $€ 20,000$ per year and not contributing to a supplementary pension). Using Survey of Income and Living Conditions (SILC) data, they found that, for those with incomes between $€ 20,000$ and $€ 30,000,93$ per cent would have net replacement rates that, adjusted for mortgage costs, would be below 70 per cent.

However, replacement rates are sensitive to how income (both pre- and postretirement) is defined, and generally do not take into account the wider resources of the household (e.g. from other family members and/or from assets), or future risks to longevity, investments and healthcare needs (Knoff et al., 2016). An extensive literature has demonstrated the sensitivity of income replacement rate calculations to assumptions about the unit of analysis, definition of income and future longevity, investment and health risks (Brady, 2010; Chen et al., 2018; Hurd and Rohwedder, 2012; Poterba, 2014; Purcell, 2012). The usefulness of a single replacement rate as a policy goal has also been questioned (Congressional Budget Office, 2017; Nivakoski and Barrett, 2019).

An alternative approach assesses the adequacy of retirement income by determining whether it is sufficient to meet basic needs (i.e. having enough income to be able to purchase necessities such as housing, food and clothing). This is assessed in terms of whether retirement resources are below some benchmark of income poverty, typically the at-risk-of-poverty threshold. A combination of indicators is recommended when assessing retirement income adequacy as a high replacement rate may not necessarily reflect a high level of income in retirement, and an income level just above a poverty threshold does not necessarily imply a high replacement rate (Banks et al., 2012; Congressional Budget Office, 2017; Knoff et al., 2016).

In this context, a number of studies have attempted to move beyond a single replacement rate to consider multiple indicators of retirement income adequacy, varying not only the definition of income, but also the benchmarks used to assess adequacy. A series of studies in England, using data from the English Longitudinal

\footnotetext{
${ }^{4}$ Auto-enrolment (the Automatic Enrolment Retirement Savings System) is due to be introduced in 2022. Under auto-enrolment, employees without personal retirement savings and who meet certain age and earnings criteria will be automatically enrolled into a state-sponsored quality-assured supplementary retirement savings system, with freedom of choice to opt out. See: https://www.gov.ie/en/consultation/1816502908-automaticenrolment-retirement-savings-system/
} 
Study on Ageing (ELSA), illustrate the benefits of this approach. Banks et al. (2005) used data on nearly 5,000 individuals aged between 50 and the SPA from the 2002/2003 ELSA to calculate the fraction of the sample whose retirement resources were below different benchmarks for adequate retirement resources. Two broad indicators of retirement income adequacy were constructed, one based on a poverty line defined by the pension credit guarantee (a level below which the benefit system will not allow incomes to fall), and a second based on income replacement rates. They found that only 7 per cent of the over-50s fell below the poverty line, that 11 per cent had less than a two-thirds replacement rate, and that 23 per cent had less than an 80 per cent replacement rate. Multivariate analysis showed that individuals who had high current income (for example, those in paid work) were more likely to be at risk of having low replacement rates in retirement. In contrast, it was the lifetime-poor (those with low levels of education, those in poor health and those out of work who did not consider themselves retired) who were most at risk of having retirement incomes below the pension credit guarantee, even if their retirement income was predicted to be high relative to their current income. Further analysis of those at risk of inadequate resources in retirement, using the same data, analysed the distribution of those at risk across income groups and employment status, and assessed the sensitivity of the estimates to differing definitions of retirement resources. They found, for example, that 9.2 per cent of those in the lowest earnings band $(<£ 8,000$ in 2002/2003) would fall below the UK Pensions Commission 'at risk' benchmark on the basis of pension wealth, rising to 46.8 per cent among those in the highest earnings band $(>£ 26,000) .{ }^{5}$ Using the most comprehensive definition of wealth (i.e. incorporating owner-occupied housing, expected inheritances and pension credit) reduced these proportions to 0.3 per cent and 19.9 per cent respectively (Emmerson and Tetlow, 2006).

Crawford and O'Dea (2012) updated these analyses using later waves of the ELSA (covering the period 2004 to 2010) to provide a new assessment of the proportion of people aged between 50 and the SPA who were at risk of having inadequate resources in retirement. Their main analysis covered over 2,500 individuals surveyed in 2008/2009. They considered six definitions of what constitutes income in retirement, ranging from pension income (private and state), to the broadest measure of income that included pension income, the annuitised value of nonhousing wealth, expected inheritances, means-tested pension credit and imputed rental income from owner-occupied housing wealth. Four benchmarks of pension income adequacy were considered; a poverty line (i.e. the pension credit guaranteed level of income), and three income replacement rates (67 per cent of net family income, 80 per cent and a threshold that varied with pre-retirement gross earnings). They found that 12 per cent of individuals would have an income

\footnotetext{
${ }^{5}$ Adequacy was assessed against the 2004 UK Pensions Commission benchmark, which varied the income replacement rate with earnings (from 80 per cent for those earning less than $£ 8,000$ to 50 per cent for those earning $£ 40,000$ or more).
} 
at the SPA of less than the pension credit guarantee, using a definition of income that included only state and private pension income. Using the same definition of income, 41 per cent of individuals would replace less than 67 per cent of their current net family income, while 53 per cent would replace less than 80 per cent. Redefining income to incorporate the broadest definition reduced these proportions considerably; for example, the proportion of individuals at risk of replacing less than 67 per cent of their current income fell to 10 per cent. Multivariate regression analysis of the factors associated with the median income replacement rate showed that, while the higher-educated had significantly lower income replacement rates using the basic definition of income, this difference was no longer statistically significant when using the more comprehensive definition of income that incorporated financial and housing wealth. Comparisons between $2004 / 2005$ and 2009/2010 showed that the proportion of individuals at risk of inadequate resources in retirement had fallen. ${ }^{6}$

This paper takes a similar approach to Banks et al. (2005) and Crawford and O'Dea (2012) for Ireland. We examine both replacement rate and poverty-line benchmarks of income adequacy for a birth cohort who will reach the (current) state pension age of 67 between 2022 and 2027. Born between 1955 and 1960, these are the youngest adults surveyed by the first wave of TILDA, which included detailed questions on individuals' asset holdings and employment histories. We use this information to simulate forward these adults' likely incomes in retirement, from both private and public sources. The individual is the unit of analysis, but where individuals are part of a couple, we take into account the income of the partner to calculate household equivalised income.

The remainder of this report proceeds as follows. Chapter 2 briefly outlines the current public and private pension system in Ireland. Chapter 3 summarises the data we use and our methodological approach, with more detailed technical documentation found in Appendix 1. Chapter 4 presents the results of our analysis, and their implications for policy are discussed in Chapter 5 , which also concludes.

\footnotetext{
${ }^{6}$ However, non-random attrition from ELSA over time means that this result should be treated with caution.
} 


\section{Irish Pension System}

Before introducing the data and methods, we briefly describe the current Irish pension system, given its importance to incomes in retirement. Data from the Irish Survey of Income and Living Conditions (SILC) for 2011 show that just over 80 per cent of the gross income of the population aged $65+$ comprises income from the three main pillars of the pension system: state, occupational and private pensions (CSO, 2013).

The first of these pillars is the most extensive. The latest official figures show that only 56.3 per cent of those aged 20 to 69 in employment in 2018 were covered by an occupational or private pension (CSO, 2019b). This first pillar comprises the state (contributory or non-contributory) pension, which is a largely flat-rate payment (i.e. not earnings-related), payable from age 66. Entitlement to the state pension (contributory) is based on a complex set of rules, and depends on when the individual first entered employment, the number of pay-related social insurance (PRSI) contributions, and the average number of contributions per year. ${ }^{7}$ To qualify for the non-contributory state welfare pension, a person must pass a means test based on both income and wealth, and must be habitually resident in Ireland (Nivakoski and Barrett, 2019). ${ }^{8}$

The SPA in Ireland is currently 66, with no provision to defer any entitlement or to claim it earlier. Prior to 2014, the state pension (transition) in Ireland was payable at age 65 to individuals who retired from insurable employment and satisfied certain social insurance contribution conditions. The state pension (transition) was abolished in 2014. For both the contributory and non-contributory state pensions, the SPA will further increase to 67 in 2021 and to 68 in 2028 (Government of Ireland, 2018). In 2018 in Ireland, the effective retirement age ${ }^{9}$ for men was 65.6, and 64.1 for women (OECD, 2019).

The second pillar comprises occupational pensions, which cover a broad section of

\footnotetext{
${ }^{7}$ It is proposed to move to a new 'total contributions approach' (TCA) for determining the level of contributory pension received by an individual. Under this system, the amount of pensions will be directly proportionate to the number of social insurance contributions made by a person over his or her working life, rather than the average (Government of Ireland, 2018). While this was initially intended to be fully rolled out for those retiring in 2020 onwards, those reaching the SPA are currently being assessed under the existing and TCA systems and given an entitlement corresponding to the higher of the two.

${ }^{8}$ The maximum contributory state pension payable in 2010, when wave 1 of the TILDA dataset was collected, was $€ 230.30$ per week, corresponding to 33.1 per cent of average earnings (using the CSO Earnings and Labour Costs measure of average earnings). The non-contributory state pension is means-tested and was capped at a pre-tax rate of $€ 219$ per week in 2010 (Nolan et al., 2019).

${ }^{9}$ The effective retirement age is the average age of labour market exit. It is generally lower than the state pension age (SPA) (OECD, 2019).
} 
the population. ${ }^{10}$ Tax relief at the marginal rate is available for contributions to approved occupational pension schemes. It is generally not possible to contribute to an occupational pension scheme after the normal age of retirement. There is no legal obligation for employers to provide occupational pension schemes, but those who do not must provide access to at least one Personal Retirement Savings Account (PRSA). However, public service occupational pension schemes are in place for staff across the civil service, local authorities, Garda Síochána (Irish police), the Defence Forces, the health and education sectors and non-commercial state bodies. Along with New Zealand, Ireland is the only OECD country without mandatory earnings-related pension provision (OECD, 2014), although recent reforms in the UK abolished such provision since 2016 (Crawford et al., 2013).

Finally, the third pillar is a voluntary savings pillar, typically comprised of long-term personal savings and financial investments used to fund retirement over and above first and second-pillar arrangements. Private pension schemes are voluntary and include Retirement Annuity Contracts (RACs), commonly used by the selfemployed, and PRSAs, which were introduced in 2002 as an attempt to increase the pension coverage among low-coverage employee groups (Nolan et al., 2019).

${ }^{10}$ Of those covered by an occupational or personal pension in 2018, 63.7 per cent had an occupational pension only, 16 per cent a personal pension only, and 20.3 per cent had both (CSO, 2019b). 


\section{CHAPTER 3}

\section{Summary of Data and Methods}

In this paper, we use data from the Irish Longitudinal Study on Ageing (TILDA). TILDA is a nationally representative survey of community-dwelling individuals aged 50 years and over, and their spouses or partners of any age (i.e. individuals living in nursing homes or other institutions were excluded at baseline). The study is harmonised with other international longitudinal studies of ageing, such as the US Health and Retirement Study (HRS), the Survey of Health, Ageing and Retirement in Europe (SHARE) and the English Longitudinal Study on Ageing (ELSA). The dataset contains a rich set of variables on the demographic, health and socio-economic circumstances of older people in Ireland. Data are collected primarily via computer-aided personal interviewing (CAPI). Data collection for the first wave took place over the period October 2009 to February 2011, when 8,504 individuals were sampled, of whom 8,175 were aged 50+ years (Barrett et al., 2011). ${ }^{11}$ Further information on the sample design is available elsewhere (Whelan and Savva, 2013).

We use data from wave 1 in this paper, focusing on the sample of those who were born between 1955 and 1960, i.e. those aged between 50 and 55 at TILDA wave 1. These individuals have a state pension age (SPA) of 67, with an expected date of receipt ranging from 2022 to 2027 . A number of these individuals reported being retired at the time of the 2010 TILDA survey $(n=58)$. We drop them from our sample, as we cannot observe their incomes before retirement and so cannot calculate replacement rates for them, leaving a final sample size of 1,904.

The main outcome of interest in this paper is household-level income at the point of retirement, assumed to be age 67, the SPA. We analyse predicted values of this variable for our cohort of interest, the first of whom will retire in 2022. Therefore, our goal is to use the information provided in the TILDA questionnaire to predict the future income in retirement of participants in our cohort of interest. The TILDA survey provides the requisite information to predict future incomes in retirement. The survey collects data on participants' earnings, current employment status, employment history and asset holdings, alongside comprehensive information on the details of their occupational and personal pension schemes. Information on demographics, family circumstances and other related factors is also provided, which can be combined with income and asset information to generate predictions of future retirement income.

Our approach follows that of O'Dea and Crawford (2012) in attempting to examine the adequacy of incomes in retirement for individuals approaching the SPA over

\footnotetext{
${ }^{11}$ The second wave of TILDA was carried out between April 2012 and March 2013, wave 3 between March 2014 and October 2015, and wave 4 between January 2016 and December 2016, with response rates ranging from 84 to 88 per cent (Donoghue et al., 2018). Data from waves 5 (2018) and waves 6 (2020) will soon be available.
} 
the period 2022-2027. Following their approach, we assess retirement income adequacy for our cohort against a variety of benchmarks of adequacy, relating income in retirement both to that immediately before retirement and to some minimum level of resources considered adequate to buy essential goods and services. ${ }^{12}$

In both cases, decisions over what constitutes 'income' in retirement also need to be considered; e.g. should the imputed income from owner-occupied housing wealth be considered as a source of income for retirement? Here, we consider three definitions of income, which differ in their treatment of assets accumulated before retirement. Our first definition of income, which we refer to as narrow income, is income derived from the public and private pensions of household members, and market income of spouses who are still in work, less applicable income taxes. The second adds asset income, while the third adds half the value of imputed income from owner-occupied housing wealth. This reflects the fact that a couple or single adult with housing wealth is, all else being equal, better off than one without. Housing wealth may be converted into income, and/or those with owner-occupied housing wealth do not have to pay rent. Where the individual is a member of a couple, incomes of both partners are considered and total household income is adjusted for household size. ${ }^{13}$

The technical appendix contains full details on the data sources, assumptions and methods used to calculate income under each of these three definitions, both preand post-retirement, for our cohort. However, at this point it is worth noting two key assumptions that underlie our analysis.

First, individuals are assumed to retire when they reach the SPA of 67 . While Banks et al. (2005) assumed that individuals retire according to their recorded expectations of working past a certain age in the ELSA, it is likely that such expectations themselves depend on expectations of available income in retirement, with those who are inadequately prepared choosing to delay retirement. Moreover, calculating predicted retirement income when each individual reaches the SPA provides a consistent measure of the distribution of future resources that is not affected by changes to family circumstances, future health status, preferences for working life, etc.

Second, we assume the circumstances and behaviours recorded by our cohort in 2010 (when individuals in the cohort were aged between 50 and 55) remain

\footnotetext{
${ }^{12}$ As described in Appendix 1, our measure of disposable income before retirement is taken from the single comprehensive income question in TILDA, which O'Sullivan et al. (2014) show significantly understates average disposable income relative to SILC. This means that the replacement rate measures of income adequacy we examine later may be overstated, and so the levels of income inadequacy on this measure may be understated. ${ }^{13}$ We use the national (CSO) equivalence scale, which gives the first adult in a household a weight of 1 , subsequent adults aged 14+ a weight of 0.66 and any children a weight of 0.33 .
} 
constant until the individual reaches the SPA. Importantly, we assume employment and welfare status remains constant from the point of the survey until the SPA, that earnings rise in line with forecast wage growth, and that those who have supplementary defined contribution (DC) pensions continue to make contributions until they reach retirement. Given that earnings follow a distinct age profile, peaking for both men and women around age 50 (CSO, 2019c), this suggests that we are examining replacement rate measures of income adequacy relative to quite a demanding benchmark (final or near-final earnings). For example, Crawford and O'Dea (2020) find that, while almost 90 per cent of those born in England in the 1940s will replace less than 70 per cent of their pre-retirement earnings in retirement, only a third will replace less than this fraction of their average working life earnings. The authors argue, convincingly, that replacement rates out of lifetime income may be a more relevant concept when considering the adequacy of income in retirement. However, due to data limitations we are restricted to examining income prior to retirement measured at a single point in time.

Figure 3.1 shows the simulated distribution of disposable income in retirement adjusted (equivalised) for family size on each of our three definitions of income. With the narrowest of these definitions, there is a large spike at around $€ 16,000$ per year. This is somewhat above the annualised level of the maximum state pension we simulate will be in place by 2022 , and reflects the fact that the state pension comprises the main source of income in retirement for most of this cohort, with few entitled to substantial private and occupational pension income.

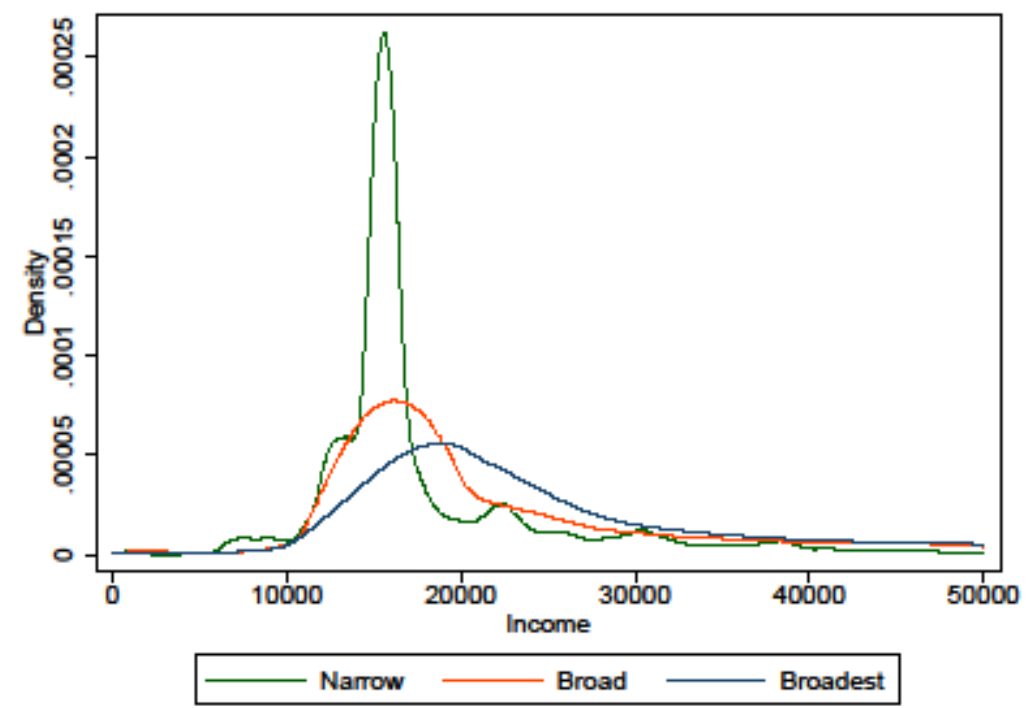

Sources: Authors' calculations using data from the Irish Longitudinal Study of Ageing (TILDA). Note: The figure shows the distribution of equivalised disposable income using the modified OECD scales under each of
our three definitions of income. 'Narrow' includes just state, occupational and private pension income. 'Broad' adds to this the annuitised value of net-financial assets excluding primary residences. 'Broadest' adds to this half the annuitised value of primary residences. 


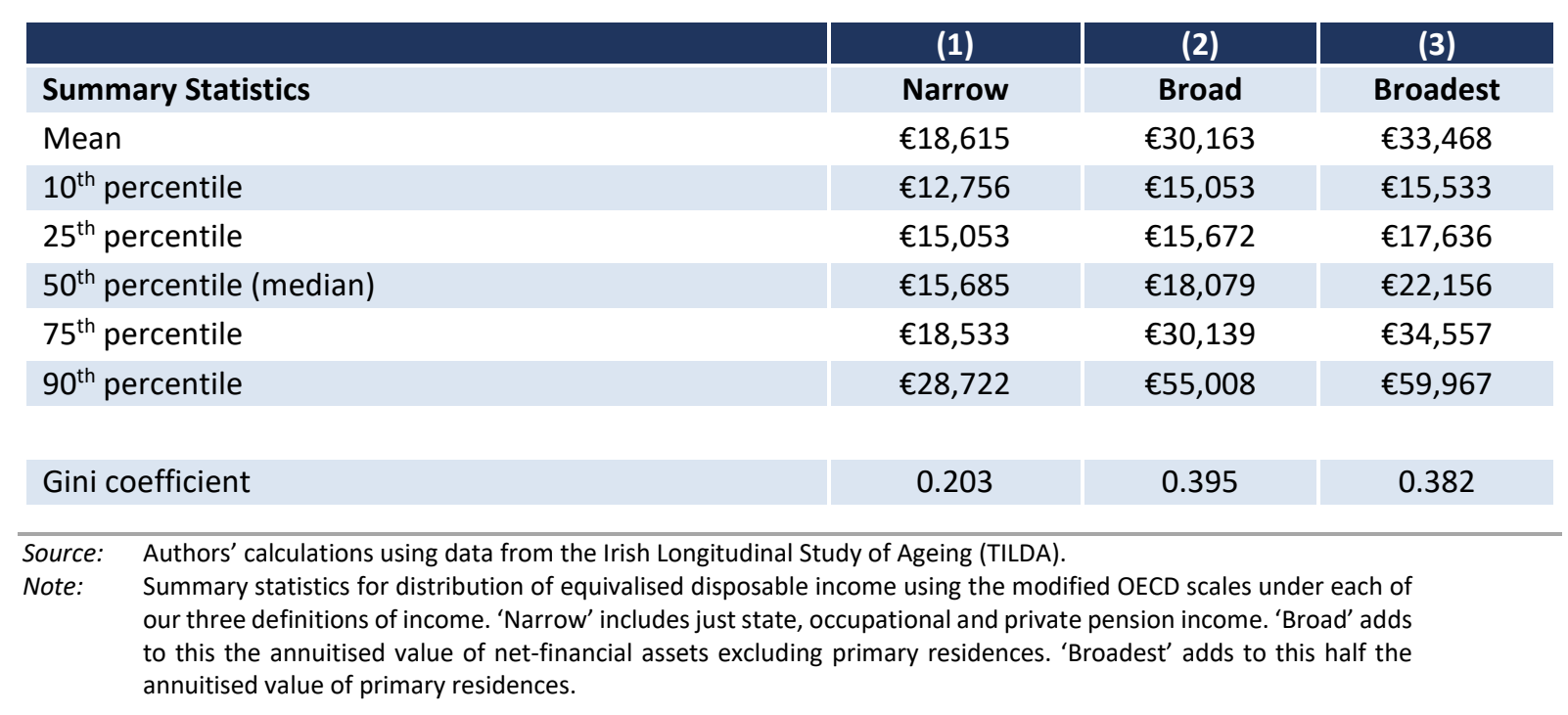

However, expanding the definition of income to include the annuitised value of net-financial assets (the 'broad' series) changes the shape of the distribution significantly. As shown in Table 3.1, it raises median equivalised disposable income from $€ 15,685$ to $€ 18,079$, with much bigger increases higher up the distribution. Indeed, Table 3.1 also shows that widening the definition of income increases the mean value from $€ 18,615$ to $€ 30,163$, but the $90^{\text {th }}$ percentile from $€ 28,722$ to $€ 55,008$. Similarly, widening the definition further to include half the annuitised value of primary residences results in a much more dispersed distribution of income, with a median value of $€ 22,156$ and a mean of $€ 33,468$.

This greater dispersion of income is also reflected in the much larger Gini coefficients - a summary measure of inequality ranging from 0 (where everyone has the same income) to 1 (where one person has all the income) - for more broadly defined measures of income: $0.203,0.395$ and 0.382 for the narrow, broad and broadest measures of income respectively. The following chapter builds on this analysis to assess the adequacy of these simulated retirement incomes against various benchmarks. 


\section{CHAPTER 4}

\section{Results}

Assessing the adequacy of incomes in retirement is not a straightforward task. As discussed in Chapter 3, a number of assumptions are required to simulate what this income is likely to be, while there are multiple definitions of what one may want to consider as income. However, even if the income a family will have in retirement could be known with certainty, further assumptions are needed to make any claims about its adequacy. Two broad approaches have emerged in the literature and policy discussions. The first considers adequacy with reference to an individual's previous levels of income: a replacement rate approach. The second considers adequacy with reference to some fixed level of income deemed sufficient to buy essential goods and services: a poverty-line approach.

Neither approach provides a definitive answer to whether those approaching the state pension age (SPA) will have an adequate income in retirement, while both embed certain - ultimately subjective - assumptions about what should be deemed an 'adequate' income in retirement. We therefore consider a range of measures under both approaches in this chapter, discussing some of the underlying assumptions and shortcomings of each. ${ }^{14}$ Taken together, these can further our understanding of which groups may be at risk of having insufficient resources to provide for their needs in retirement.

\subsection{REPLACEMENT RATE MEASURES}

We first consider replacement rate measures of income adequacy. These conceive of adequacy as related to an individual's income during their working life, with those replacing less than a certain proportion of their pre-retirement income in retirement deemed to have inadequate income. Such measures are theoretically grounded in a long-standing economics literature that emphasises the desire of individuals to smooth the profile of consumption over their lifecycles, avoiding significant volatility where possible. ${ }^{15}$ In addition, they have the attractive feature of being relatively simple to calculate and intuitive to understand.

However, these measures have a number of shortcomings. First, the preretirement income that constitutes the denominator is measured at a particular snapshot in time, so may not give a fair reflection of living standards in working life if incomes are particularly volatile or subject to substantial measurement error. This may lead to the degree of income adequacy being over- or understated, depending on the nature of the volatility and measurement error.

\footnotetext{
${ }^{14}$ For a good discussion of these issues, see also pp.14-19 of Crawford and O'Dea (2012).

${ }^{15}$ Browning and Crossley (2001) provide a summary of this literature and the empirical evidence to support it.
} 
Second, the potential mismeasurement of working-life living standards may be exacerbated if older adults 'phase' into retirement, reducing their hours of work or work intensity as they approach the SPA. This could lead us to overstate the adequacy of incomes in retirement by understating the level of incomes during working life. Third, and more substantively, it is not clear that the same level of income in retirement is needed to obtain a given standard of living in working life. Retirees do not face many costs associated with work - for example, commuting costs - and have more leisure time, some of which can be used to achieve desired consumption at a lower cost; for example, shopping around for lower-cost groceries or cooking from scratch rather than eating prepared meals (Aguiar and Hurst, 2005). They also do not have to save for retirement, having at that stage retired. On the other hand, retirement may be associated with greater health and social care costs than in working life. All this suggests that comparisons to income in working life do not provide an unambiguously clear indication of the adequacy of income in retirement.

Nevertheless, replacement rate measures of income adequacy have been to the forefront of pension policy debates in Ireland over recent decades. Since it was recommended in the National Pensions Policy Initiative (National Pensions Board, 1998), successive governments have formally adopted, endorsed or referenced an income adequacy benchmark based on replacing 50 per cent of gross preretirement earnings in retirement. ${ }^{16}$

The first column in Table 4.1 shows the proportion of individuals who replace less than 50 per cent of their gross pre-retirement earnings $\left(Y_{e}^{w}\right)$ in retirement for each of the three income measures described in Chapter 3; that is, the share for whom $\frac{Y_{m}^{r}}{Y_{e}^{w}}<0.5$ where $Y_{m}^{r}$ is disposable income in retirement using successively broader definitions of income $\left(Y_{m 1}^{r}, Y_{m 2}^{r}, Y_{m 3}^{r}\right)$.

On the narrowest definition of income $\left(Y_{m 1}^{r}\right)$, just over a fifth of those approaching the SPA replace less than half of their pre-retirement earnings. This falls to 16.7 per cent when one includes the annuitised value of net-financial assets (excluding primary residences, $Y_{m 2}^{r}$ ) in the definition of income, and 12 per cent when half the annuitised value of primary residences is added to this $\left(Y_{m 3}^{r}\right)$.

\footnotetext{
${ }^{16}$ See Rec. 9 S.5.1.7 in National Pensions Board (1998), reaffirmed by National Pensions Board (2006) and the Green Paper on Pensions (Government of Ireland, 2007). While the more recent Roadmap for Pensions Reform (Government of Ireland, 2018) does not set a formal target of income adequacy, it does cite $50-60 \%$ as 'a sufficient proportion ... of an individual's pre-retirement earnings so as to enable the individual concerned to maintain a reasonable standard of living after retirement'.
} 


\begin{tabular}{|l|c|c|c|}
\hline & (1) & (2) & (3) \\
\hline Share with income in retirement that is: & $<50 \%$ earnings & $<67 \%$ income & $<80 \%$ income \\
\hline Measure of income in retirement: & & & 0.545 \\
\hline Narrow $\left(\boldsymbol{Y}_{\boldsymbol{m} \mathbf{1}}^{r}\right)$ & 0.230 & 0.419 & 0.501 \\
\hline Plus annuitised value of net-financial assets $\left(\boldsymbol{Y}_{\boldsymbol{m} 2}^{\boldsymbol{r}}\right)$ & 0.167 & 0.361 & 0.446 \\
\hline Plus half annuitised value of primary residences $\left(\boldsymbol{Y}_{\boldsymbol{m} 3}^{\boldsymbol{r}}\right)$ & 0.120 & & \\
\hline
\end{tabular}

Source: Authors' calculations using data from the Irish Longitudinal Study of Ageing (TILDA).

Note: Replacement rates calculated at an individual level comparing equivalised household disposable income in retirement to equivalised household gross earnings before retirement (column 1 ) and equivalised disposable income before retirement (columns 2 and 3 ).

While comparing income from all sources in retirement to just earnings from employment (and self-employment) during working life is common, Nivakoski and Barrett (2019) show that it can yield potentially misleading results. This is not least because the measure is defined only for those with positive pre-retirement earnings, excluding from consideration those without any earnings. They show that comparisons of more comprehensive measures of pre- and post-retirement income - including not just earnings but income from social welfare benefits and other sources - give lower replacement rates at the top and the bottom of the distribution. Such measures are also arguably more reflective of the resources available before retirement and thus of how adequately those approaching the SPA will be able to replicate those standards of living in retirement (with the caveats discussed above).

Table 4.1 shows the share of individuals whose disposable income in retirement is less than 67 per cent (col. 2) and 80 per cent (col. 3) of their pre-retirement household disposable income $\left(Y_{D}^{W}\right)$. These benchmarks have been used elsewhere (e.g. Crawford and O'Dea, 2012) and suggest a far larger proportion of individuals are at risk of having an inadequate income in retirement than the earnings-related benchmark does. Indeed, our simulations project that, on the narrowest definition of income in retirement, over half of those approaching the SPA will replace less than 67 per cent of their pre-retirement disposable income while more than 6 in 10 will replace less than 80 per cent. However, these shares fall substantially - to 41.9 per cent and 50.1 per cent respectively - when one includes the annuitised value of net-financial assets, and further still - to 36.1 per cent and 44.6 per cent when half the annuitised value of primary residences is added. 


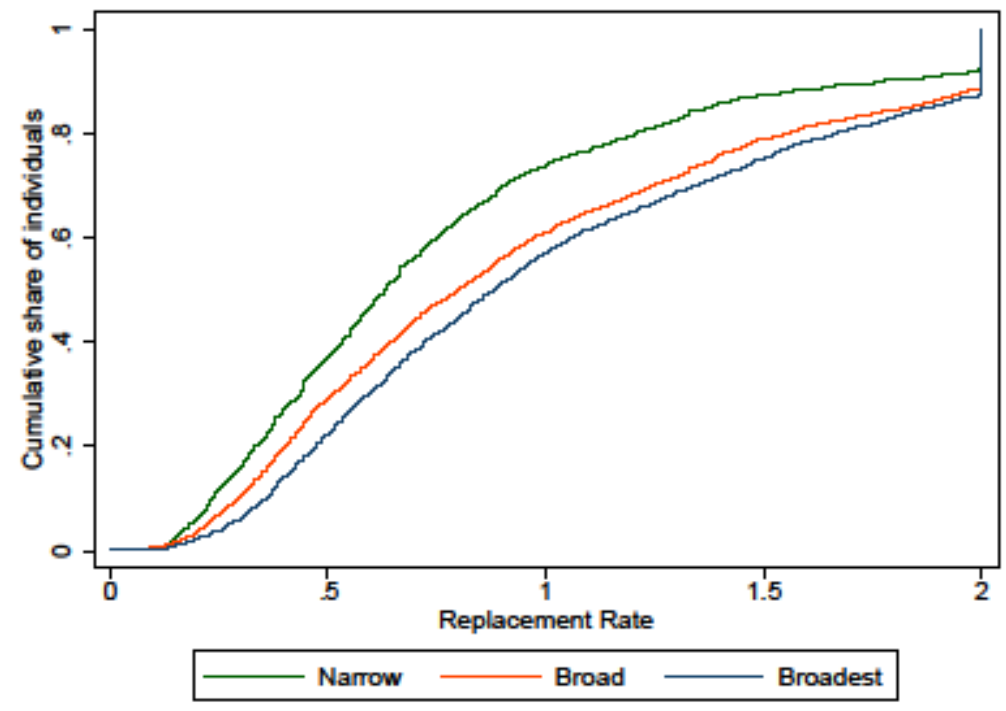

Sources: Authors' calculations using data from the Irish Longitudinal Study of Ageing (TILDA).

Note: $\quad$ Replacement rates calculated at an individual level comparing equivalised household disposable income in retirement to equivalised household disposable income before retirement.

The share of individuals classified as being at risk of having inadequate income is also quite sensitive to the level at which the adequacy benchmark is defined. Figure 4.1 plots the cumulative distribution of household income replacement rates for each measure of disposable income. The steepness of the lines between 0.5 and 0.75 on the horizontal axis show that a large number of individuals replace around two-thirds of pre-retirement disposable income in retirement. ${ }^{17}$ As a result, the precise replacement rate cut-off used for the adequacy benchmark can lead to quite different shares of individuals deemed to be at risk of having an inadequate income in retirement. For example, setting this at half of pre-retirement disposable income reduces the proportion classified as at risk of having inadequate income in retirement to less than 40 per cent, using the narrow definition of income, down from 54.5 per cent when set at two-thirds.

We now turn to look at which groups of individuals are at greater risk of having an inadequate income in retirement on the basis of these replacement rate benchmarks. Table 4.2 displays the odds ratios from logistic regressions of individual characteristics on the probability of having (narrowly defined) disposable income in retirement below each of the three adequacy benchmarks. ${ }^{18}$ These coefficients are best explained with an example. An odds ratio of 2 says that an individual in group A faces twice the chance of someone in the excluded group

\footnotetext{
${ }^{17}$ Note that Figure 4.1 plots replacement rates using pre-retirement household disposable income as the denominator while the first column of Table 4.1 uses pre-retirement earnings as the denominator.

${ }^{18}$ Tables A2.1 and A2.2 in the Appendix present similar models for the 'broad' (including annuitised value of net financial assets) and 'broadest' (including also half the annuitised value of primary residence) definitions of post-retirement income respectively.
} 
$\mathrm{B}$ of having an inadequate income in retirement. ${ }^{19}$ The key information to take from Table 4.2 is whether the coefficient is above or below 1, indicating that an individual with a certain characteristic (e.g. a woman) has respectively a greater or lower chance of having inadequate income in retirement than a similar individual in the excluded category (in this example, a man).

TABLE 4.2 LOGISTIC REGRESSION OF REPLACEMENT RATE INCOME ADEQUACY BENCHMARK

\begin{tabular}{|c|c|c|c|}
\hline \multirow{2}{*}{ Share with income in retirement that is: } & (1) & (2) & (3) \\
\hline & $<50 \%$ earnings & $<67 \%$ income & $<80 \%$ income \\
\hline \multicolumn{4}{|l|}{ Living in } \\
\hline \multicolumn{4}{|l|}{ Dublin (reference) } \\
\hline Urban area outside Dublin & 0.713 & $0.642^{* *}$ & $0.728^{*}$ \\
\hline Rural area & $0.644^{*}$ & $0.725^{*}$ & 0.824 \\
\hline \multicolumn{4}{|l|}{ Household type } \\
\hline \multicolumn{4}{|l|}{ Non-farming household (reference) } \\
\hline Farming household & 0.614 & 0.823 & 0.958 \\
\hline \multicolumn{4}{|l|}{ Cohabitation status in working life } \\
\hline \multicolumn{4}{|l|}{ Married/cohabitating (reference) } \\
\hline Single & $12.913^{* * *}$ & $5.472^{* * *}$ & $3.977^{* * *}$ \\
\hline \multicolumn{4}{|l|}{ Gender } \\
\hline \multicolumn{4}{|l|}{ Man (reference) } \\
\hline Woman & $0.525^{* * *}$ & $0.587^{* * *}$ & $0.597^{* * *}$ \\
\hline \multicolumn{4}{|l|}{ Education } \\
\hline \multicolumn{4}{|l|}{ Primary or lower (reference) } \\
\hline Lower secondary & 1.890 & 1.349 & $1.394^{*}$ \\
\hline Upper secondary & $3.753^{* * *}$ & $1.725^{* *}$ & $1.641^{* *}$ \\
\hline Post-secondary < degree & $3.704^{* * *}$ & $1.895^{* * *}$ & $1.973^{* * *}$ \\
\hline Post-secondary degree or higher & $11.136^{* * *}$ & $3.292^{* * *}$ & $3.319^{* * *}$ \\
\hline Observations & 1392 & 1904 & 1904 \\
\hline \multicolumn{4}{|c|}{$\begin{array}{ll}\text { Source: } & \text { Authors' calculations using data from the Irish Longitudinal Study of Ageing (TILDA). } \\
\text { Note: } & \text { Coefficients show odd-ratios from logistic regressions. Stars show statistical significance, indicating a p value of }< \\
& 0.05\left({ }^{*}\right),<0.01(* *) \text { and }<0.001\left(*^{* *}\right) \text { respectively. Replacement rates are calculated at an individual level comparing } \\
& \text { equivalised household disposable income in retirement (narrowly defined) to equivalised household earnings before } \\
& \text { retirement, excluding } 512 \text { individuals without any earnings (column } 1 \text { ) and equivalised disposable income before } \\
& \text { retirement (columns } 2 \text { and } 3 \text { ). }\end{array}$} \\
\hline
\end{tabular}

The first set of coefficients shows that there is no statistically significant difference

\footnotetext{
${ }^{19}$ These allow us to easily compare the relative chance that someone in each group has of having inadequate income in retirement (which is constant across other covariates), but do not allow the absolute or relative risk of income adequacy to be directly inferred (as these depend on the values taken by other covariates).
} 
between those living in Dublin and living outside of Dublin in the probability of replacing a small share of their earnings in retirement (col. 1), less than 67 per cent of their disposable income in retirement (col. 2) and less than 80 per cent of this income (col. 3).

Similarly, while the next set of estimates shows that being part of a farming household increases the odds of someone having income below the adequacy benchmarks, none of these is statistically significant. However, as Table A2.1 in the Appendix shows, when the annuitised value of net-financial assets is included in the definition of income, those in farming households are significantly less likely to replace a small share of their pre-retirement earnings or disposable income.

One characteristic that stands out as having an extremely strong association with being at risk of having an inadequate income in retirement is someone's cohabitation status when we observe them in the first wave of TILDA. The estimates suggest that singles are far more likely than those married or cohabitating to replace less than half their earnings in retirement or to replace less than 67 per cent or 80 per cent of their working-life income. All estimates are statistically significant at even the 99.9 per cent level of confidence.

While not as large in magnitude, the estimates also show that women have a much smaller chance than men of having an inadequate income in retirement on the basis of the three replacement rate measures. Similarly, the estimates suggest that those with more than upper secondary education (e.g. the Leaving Certificate) are more likely to replace a small share of their earnings or disposable income in retirement, with all estimates statistically significant at the 99.9 per cent level of confidence.

These last results may appear somewhat counter-intuitive, but illustrate an important feature of the Irish pension system that affects replacement rate measures of adequacy. They arise because both men and more highly educated adults are more likely to have higher earnings/income during working life and given that the contributory state pension depends only on the number of years worked, not earnings - to replace a lower share of these earnings in retirement. Indeed, Nivakoski and Barrett (2019) show that those with low levels of earnings in working life have higher replacement rates than those with middle or even high levels of earnings. Caution is therefore required in the use of replacement rate measures of income adequacy in isolation. For that reason, we now also examine poverty-line measures of income adequacy. 


\subsection{POVERTY-LINE MEASURES}

Poverty-line measures conceive of income adequacy as related to a minimum of resources needed to buy essential goods and services. This raises the obvious question of what should be considered an essential good or service, answers to which are ultimately subjective and evolve over time. We examine three definitions that form part of policy discussions both in Ireland and abroad.

The first classifies those with income (adjusted for household size) below 60 per cent of the national median to have inadequate income. This headcount measure aligns with the official at-risk-of-poverty rate published annually by the CSO. Table 4.3 shows that, on this basis and using the narrowest definition of income, 24.4 per cent of those approaching the SPA are likely to have inadequate income in retirement, double the published at-risk-of-poverty rate for retired individuals in 2018. ${ }^{20}$ However, as with replacement rate measures of adequacy, when one includes the annuitised value of net-financial assets and half the annuitised value of primary residences, this rate falls markedly - to 9.2 and 5.4 per cent respectively.

The share of individuals classified as having inadequate income also falls dramatically if we use an alternative benchmark that aligns with the OECD definition of the poverty rate. On this measure - having income below 50 per cent rather than 60 per cent of the national median - only about a third as many individuals are classified as having inadequate income using the narrowest definition of income: 7.1 compared to 24.4 per cent. Including the annuitised value of net-financial assets in income reduces this further still (to 3 per cent), and the proportion falls to just over 2 per cent when half the annuitised value of primary residences is included. These are substantial differences that are important to understand in any assessment of income adequacy in retirement.

\begin{tabular}{|c|c|c|c|}
\hline & (1) & (2) & (3) \\
\hline Share with income in retirement that is: & $<60 \%$ median & $<50 \%$ median & $<M E S L$ \\
\hline \multicolumn{4}{|l|}{ Measure of income in retirement: } \\
\hline Narrow & 0.244 & 0.071 & 0.275 \\
\hline Plus annuitised value of net-financial assets & 0.092 & 0.030 & 0.168 \\
\hline Plus half annuitised value of primary residences & 0.054 & 0.021 & 0.075 \\
\hline
\end{tabular}

Source: Authors' calculations using data from the Irish Longitudinal Study of Ageing (TILDA).

Note: $\quad$ Median equivalised income for 60 and 50 per cent poverty lines taken from 2017 Survey of Income and Living Conditions, uprated by forecast wage growth. MESL (Minimum Essential Standard of Living) is calculated by the Vincentian Partnership for Social Justice (2019) for pensioner households, uprated by forecast wage growth.

20 In 2018, the at-risk-of-poverty rate (defined as below 60 per cent of median equivalised household income) was 13.7 per cent for those aged 18-64 and 11.4 per cent for those aged 65+ (CSO, 2019a). 


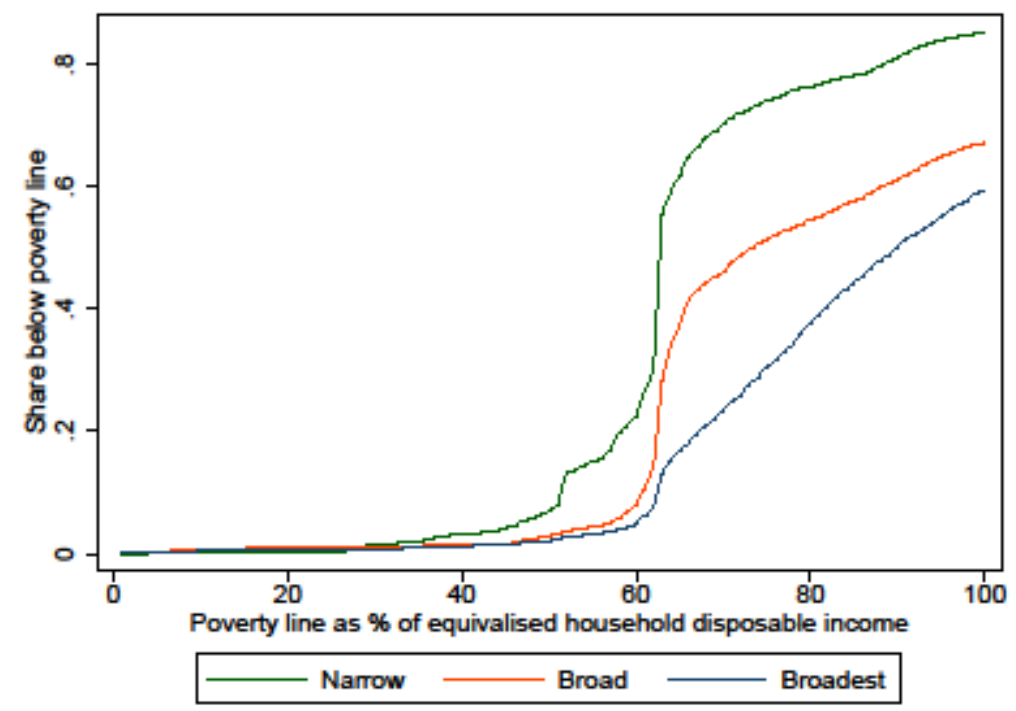

Sources: Authors' calculations using data from the Irish Longitudinal Study of Ageing (TILDA).

Note: Median income for 60 and 50 per cent poverty lines taken from 2017 Survey of Income and Living Conditions, uprated by forecast wage growth.

Figure 4.2 plots the proportion of individuals classified as having inadequate income against the proportion of national median income that the poverty line is drawn at. It shows that the dramatic difference in the share of people classified as being at risk of poverty using the 60 and 50 per cent benchmarks arises because our simulations suggest a large number of individuals can expect to have incomes in retirement that are in-and-around 60 per cent of the national median. This income level corresponds to being in receipt of a near-full contributory state pension in addition to having a small amount of private savings. The figure illustrates one of the major drawbacks of poverty-line-based measures of income adequacy: that they can be very sensitive to minor definitional differences, especially when a large number of individuals have similar levels of income.

Poverty-line thresholds like those above have also been criticised for linking the minimum resources needed to buy essential goods and services to a measure of median incomes (e.g. Sen, 1976; Atkinson, 1987; Callan and Nolan, 1991). This defines what an essential good or service is relative to what the median-or middle - household can afford to purchase.

An alternative approach is to subjectively define what should be considered essential goods or services, and calculate the income required to purchase that consumption bundle. This approach has been adopted by the Vincentian Partnership for Social Justice (2019) to calculate what it calls a Minimum Essential Standard of Living (MESL) that differs by age, geographic region of residence and household size (shown in Table 4.4). 


\begin{tabular}{l|c|c} 
& Urban & Rural \\
\hline Pensioner living alone & $€ 250.05$ & $€ 314.02$ \\
\hline Pensioner couple & $€ 315.38$ & $€ 387.46$ \\
\hline \multicolumn{2}{l}{ Source: Vincentian Partnership for Social Justice (2019). } &
\end{tabular}

The third column in Table 4.3 shows the proportion of individuals approaching the SPA that we simulate will have incomes below the relevant MESL threshold in retirement. With the narrowest definition of income, this stands at 27.5 per cent, a little higher than that classified as having inadequate income by the 60 per cent of median income benchmark. As with the other measures of adequacy, this falls substantially as the definition of income is broadened: to 16.8 per cent including the annuitised value of net-financial assets, and to 7.5 per cent after adding half the annuitised value of primary residences.

Table 4.5 presents our analysis of the characteristics associated with having inadequate income in retirement using these 'poverty line' benchmarks of adequacy. ${ }^{21}$ Whereas those living in rural areas were less likely to be classified as having inadequate income using replacement rate benchmarks, they are far more likely to be using poverty-line benchmarks. These estimates are statistically significant at the 99.9 per cent confidence level for the 60 per cent of median income and MESL benchmark, though not for the 50 per cent of median income benchmark (likely a function of the small number of individuals classified as having inadequate income under this benchmark).

The association is particularly strong for the MESL benchmark: the chances of being classified as having inadequate income are 16.7 times higher for people living in rural areas compared to those living in Dublin. Similarly, whereas farming households, women and less-educated individuals were all less likely to be at risk of having inadequate income using replacement rate benchmarks, they are more likely to be using poverty-line benchmarks (though none of these estimates is strongly statistically significant). This again reflects the fact that such individuals tend to have lower earnings and income in working life, but - given the same work history as a higher earner - receive the same level of contributory state pension. As a result, many replace a large proportion of their working-life income while simultaneously falling below poverty-line thresholds of income adequacy.

\footnotetext{
${ }^{21}$ Tables A2.3 and A2.4 in the Appendix present similar models for the 'broad' and 'broadest' definitions of post-retirement income respectively.
} 


\begin{tabular}{|c|c|c|c|}
\hline & (1) & (2) & (3) \\
\hline Share with income in retirement that is: & $<60 \%$ median & $<50 \%$ median & $<$ MESL \\
\hline \multicolumn{4}{|l|}{ Living in } \\
\hline \multicolumn{4}{|l|}{ Dublin (reference) } \\
\hline Urban area outside Dublin & 1.091 & 0.833 & 0.809 \\
\hline Rural area & $1.480 * *$ & 1.214 & $16.723^{* * *}$ \\
\hline \multicolumn{4}{|l|}{ Household type } \\
\hline \multicolumn{4}{|l|}{ Non-farming household (reference) } \\
\hline Farming household & 1.365 & 0.941 & 1.047 \\
\hline \multicolumn{4}{|l|}{ Cohabitation status in working life } \\
\hline \multicolumn{4}{|l|}{ Married/cohabitating (reference) } \\
\hline Single & $1.387^{* *}$ & 0.755 & $34.831^{* * *}$ \\
\hline \multicolumn{4}{|l|}{ Gender } \\
\hline \multicolumn{4}{|l|}{ Man (reference) } \\
\hline Woman & $1.252^{*}$ & 1.331 & 1.123 \\
\hline \multicolumn{4}{|l|}{ Education } \\
\hline \multicolumn{4}{|l|}{ Primary or lower (reference) } \\
\hline Lower secondary & 1.146 & 1.324 & $1.722^{*}$ \\
\hline Upper secondary & 0.928 & 1.071 & $1.776^{*}$ \\
\hline Post-secondary $<$ degree & 0.736 & 0.804 & 1.260 \\
\hline Post-secondary degree or higher & 0.686 & 0.982 & 1.158 \\
\hline Observations & 1904 & 1904 & 1904 \\
\hline $\begin{array}{ll}\text { Source: } & \text { Authors' calculations using data from the Ir } \\
\text { Vote: } & \text { Coefficients show odd-ratios from logistic } \\
& 0.05\left({ }^{*}\right),<0.01(* *) \text { and }<0.001\left({ }^{* * *}\right) \text { respec }\end{array}$ & $\begin{array}{l}\text { nal Study of Agein } \\
\text { Stars show statisti }\end{array}$ & $\begin{array}{l}\text { A). } \\
\text { nificance, ind }\end{array}$ & e of $<$ \\
\hline
\end{tabular}

However, one group stands out as being at particular risk of having an inadequate income in retirement on the basis of both replacement rate and poverty-line benchmarks of adequacy: those who are not married or cohabitating in the years before retirement. Our estimates in Table 4.5 suggest that the odds of such individuals having income in retirement below 60 per cent of the national median are 1.4 times higher than for those who are married or cohabitating, while the chances they have income below the MESL is 30 times higher. ${ }^{22}$

22 The odds ratio for the 50 per cent poverty line is less than 1 but is not statistically significant, reflecting the fact that only 2 per cent of our sample have incomes below this level. 


\begin{tabular}{|l|c|c|c|c|c|c|}
\hline & $(\mathbf{1})$ & $\mathbf{( 2 )}$ & $\mathbf{( 3 )}$ & $\mathbf{( 4 )}$ & (5) & (6) \\
\hline (1) $\mathrm{RR}<50 \%$ earnings & 1.000 & & & & & \\
\hline (2) $\mathrm{RR}<67 \%$ income & 0.331 & 1.000 & & & & \\
\hline (3) $\mathrm{RR}<80 \%$ income & 0.261 & 0.782 & 1.000 & & & \\
\hline (4) $\mathrm{PL}<60 \%$ median & 0.131 & 0.239 & 0.182 & 1.000 & & \\
\hline (5) $\mathrm{PL}<50 \%$ median & 0.044 & 0.096 & 0.058 & 0.369 & 1.000 & 1.000 \\
\hline (6) $\mathrm{PL}<$ MESL & 0.245 & 0.282 & 0.222 & 0.519 & 0.291 & \\
\hline
\end{tabular}

Source: Authors' calculations using data from the Irish Longitudinal Study of Ageing (TILDA).

Note: $\quad$ RR stands for replacement rate; PL for poverty line and MESL for Minimum Essential Standard of Living.

In general, the results suggest that different benchmarks give very different pictures of the extent and profile of income adequacy in retirement. This is perhaps best illustrated in Table 4.6, which displays the lack of correlation between the various benchmarks at an individual level. While to some extent this is driven by different rates of inadequacy across the benchmarks, that there is little correlation between the various benchmarks - especially between replacement rate and poverty line measures of adequacy - indicates that they are identifying different groups at risk of inadequacy in retirement. We conclude by considering the implications of these results for policy. 



\section{Conclusion}

This paper has examined the likely adequacy of incomes in retirement for those approaching the SPA over the period 2022-2027. Taking a narrow definition of income, including just private, occupational and state pension payments, our results suggest that nearly a quarter of individuals born between 1955 and 1960 will replace less than half their pre-retirement earnings in retirement - a benchmark to the forefront of government policy in recent decades. However, using the household disposable income benchmarks, far larger proportions of individuals (between 50 and 60 per cent using the narrow definition of income) are at risk of having an inadequate income in retirement. Measures of household disposable income (rather than individual earnings) are arguably more reflective of the resources available to an individual before retirement and thus of how adequately those approaching the SPA will be able to replicate those standards of living in retirement.

Yet benchmarks based on having income below a certain threshold (so-called poverty-line measures) show that a much lower share of individuals are at risk of having inadequate income from private, occupational and state pensions: about a quarter of those born between 1955 and 1960. In addition, many of those that we simulate will fall just below the 60 per cent of median income poverty line in retirement will do so by only a small amount, suggesting relatively minor changes to the generosity of the state pension could have a large effect on the future headcount at-risk-of-poverty rate for pensioners.

While this highlights how sensitive some of the commonly used benchmarks of income adequacy are to definitional differences, across all those we consider one group stands out as being at particular risk of having an inadequate income in retirement: those who are not married or cohabitating in the years before retirement. The Living Alone Increase could, therefore, be a particularly welltargeted instrument for addressing concerns about income adequacy in retirement among those approaching the SPA. This is an additional payment made to recipients of both the contributory and non-contributory state pension (as well as certain other social welfare payments). It could provide a means of targeting increases in the state pension at those who appear, across all benchmarks, to be at greatest risk of having inadequate income in their retirement.

Our results also show that private non-pension savings play an important role in individuals' preparedness for retirement. Including the annuitised value of netfinancial assets and half the annuitised value of primary residences in our definition of income substantially reduces the proportion of people replacing a small share of their pre-retirement income. It also suggests that very few will have resources 
available in retirement that place them below poverty-line measures of income adequacy, even the Minimum Essential Standard of Living (MESL) calculated by the Vincentian Partnership for Social Justice (2019).

Whether or not individuals should draw on wealth held in the form of primary residences to support living standards in retirement is a contentious and often emotive issue, not only in Ireland. ${ }^{23}$ Our inclusion of half the annuitised value of primary residences in our broadest measure of income is not a suggestion that individuals should downsize their home to one of half the value in retirement, but rather a way of reflecting the fact that a couple or single adult with housing wealth is - all else being equal - better off than one without. ${ }^{24}$ However, the extent to which future cohorts of retirees may be able to draw down owner-occupied housing wealth is likely to be more limited. Data from the most recent Census of Population indicates that the age at which two-thirds of the cohort own their own home (with or without a mortgage) has been increasing steadily over time (from 28 years of age in 1991 to 41 in 2016), ${ }^{25}$ which implies substantial differences in the projected tenure and housing costs of younger cohorts.

Less contentious is the idea that individuals should draw on their non-primary residence wealth in retirement. Much of this is accumulated precisely for such purposes, with evidence showing that these forms of savings make up an important source of expected income in retirement (Crawford, 2018). However, there is also evidence showing that individuals are reticent to draw on their nonpension, non-primary residence wealth in retirement (ibid; Lockwood, 2018). Uncertainty over future health and long-term costs, as well as the desire to leave bequests to children, may partly explain this reticence. Data from TILDA show that 90 per cent of over-50s households with adult children expect to leave a bequest to their children, and two-thirds expect to leave an inheritance of $€ 150,000$ or more (Nivakoski, 2019). Another factor that may contribute to this unwillingness is the design of capital taxes. Currently, assets transferred at death are fully exempt from Capital Gains Tax (CGT), which incentivises individuals to hold on to these assets rather than dispose of them in retirement. ${ }^{26}$ This discourages those who have bought an investment property, for example, from selling the asset and using the proceeds to achieve a higher level of living standards in retirement.

\footnotetext{
${ }^{23}$ See, for example, the discussion on pp.12-13 of Crawford and O'Dea (2012).

${ }^{24}$ Evidence on the extent to which retired individuals downsize their home is mixed. Banks et al. (2010) show that, while downsizing is common among those aged 50 and over in the United States, it is less so in England. Barrett and Kelly (2016) show there was very little evidence of downsizing among a similar-aged population in Ireland over the period 2010-2012, but this could also be explained by the dysfunctional nature of the property and residential mortgage market around this time.

25 https://www.cso.ie/en/releasesandpublications/ep/p-cp1hii/cp1hii/tr/

${ }^{26}$ While CAT applies to such bequests or gifts, it does so only above an exempt amount of $€ 335,000$ where the beneficiary is a child (including adopted child, stepchild and certain foster children) or minor child of a deceased child of the person disposing of the asset.
} 
More generally, our findings suggest that policymakers need to interpret frequently used benchmarks of income adequacy with caution, particularly those that relate income in retirement to the amount of pre-retirement earnings or income they replace. Although such replacement rate measures of income adequacy have been to the forefront of government policy in recent decades, they impose quite a demanding benchmark given that the years preceding retirement are typically when earnings and income are highest. Indeed recent work has shown that, while almost 90 per cent of those born in England in the 1940s will replace less than 70 per cent of their pre-retirement earnings in retirement, only a third will replace less than this fraction of their average working-life earnings (Crawford and O'Dea, 2020). Replacement rates out of lifetime income may be a more relevant concept when considering the adequacy of income in retirement than that when earnings are at a lifetime peak.

There is also perhaps a need for more explicit discussion about the inherent tradeoffs involved in meeting such benchmarks. Policy debates often consider more saving for retirement to be unambiguously a positive thing. In many cases it may well be. However, there is - all else being equal - a trade-off between living standards in retirement and in working life. For someone who has low levels of lifetime income, more saving for retirement comes at the expense of lower living standards during working life when needs might be high, particularly in the presence of children. While this trade-off can be relaxed by redistribution within or across cohorts, requiring individuals to save more for their retirement imposes costs during working life that should be taken account of in the formulation of pension policy. 



\section{REFERENCES}

Aguiar, M. and Hurst, E. (2005). 'Consumption versus Expenditure', Journal of Political Economy, 113(5), 919-948.

Atkinson, A. (1987). 'On the Measurement of Poverty', Econometrica, 55(4), 749-764. doi:10.2307/1911028

Banks, J., Emmerson, C., Oldfield, Z., Tetlow, G. (2005). 'Prepared for Retirement? The Adequacy and Distribution of Retirement Resources in England', Institute for Fiscal Studies, London.

Banks, J., Nazroo, J., Steptoe, A. (2012). 'The Dynamics of Ageing: Evidence from the English Longitudinal Study on Ageing 2002-2010, Institute for Fiscal Studies, London.

Barrett, A., Savva, G., Timonen, V., Kenny, R. (2011). 'Fifty Plus in Ireland 2011', The Irish Longitudinal Study on Ageing, Dublin.

Barrett, A., and Kelly, E. (2016). 'Housing and Ireland's Older Population', QEC Special Article, ESRI, Dublin.

Bercholz, M., Bergin, A., Callan, T., Garcia Rodriguez, A., Keane, C. (2019). 'A micro-macro economic analysis of pension auto-enrolment options', Working Paper No. 640, Economic and Social Research Institute, Dublin.

Brady, P. (2010). 'Measuring retirement resource adequacy', J. Pension Econ. Finance 9, 235-262. https://doi.org/10.1017/S1474747208003806

Browning, Martin, and Thomas F. Crossley (2001). 'The Life-Cycle Model of Consumption and Saving', Journal of Economic Perspectives, 15 (3): 3-22.

Callan, T., \& Nolan, B. (1991). 'Concepts of poverty and the poverty line', Journal of Economic Surveys, 5(3), 243-261.

Chen, A., Munnell, A., Sanzenbacher, J. (2018). 'How Much Income Do Retirees Actually Have? Evaluating the Evidence from Five National Datasets', Cent. Retire. Res. Boston Coll. CRR WP 2018-14.

Congressional Budget Office (2017). Measuring the Adequacy of Retirement Income: A Primer. CBO, Washington.

Crawford, R., O'Dea, C. (2012). 'The adequacy of wealth among those approaching retirement', Institute for Fiscal Studies, London.

Crawford, R., O'Dea, C. (2013). 'Retirement sorted? The adequacy and optimality of wealth among the near-retired', IFS Working Paper W14/23, Institute for Fiscal Studies, London.

Crawford, R., O'Dea, C. (2020). 'Household Portfolios and Financial Preparedness for Retirement', Quantitative Economics, 11, 637-670.

Crawford, R., Keynes, S., and Tetlow, G. (2013). 'A single-tier pension: what does it really mean?' IFS Report R82. Institute for Fiscal Studies, London. 
Crawford, R. (2018). 'The use of wealth in retirement', IFS Briefing Note BN237. Institute for Fiscal Studies, London.

CSO (2019a). Survey on Income and Living Conditions (SILC) 2018. Central Statistics Office, Dublin.

CSO (2019b). Pension Coverage Q3 2018. Central Statistics Office, Dublin.

CSO (2019c). Earnings Analysis using Administrative Data Sources 2018. Central Statistics Office, Dublin. Available at https://www.cso.ie/en/releasesandpublications/ep/peaads/earningsanalysisusingadministrativedatasources2018/age/

CSO (2013). Thematic Report on the Elderly 2004, 2009, 2010 (revised) and 2011. Central Statistics Office, Dublin.

Donoghue, O.A., McGarrigle, C.A., Foley, M., Fagan, A., Meaney, J., Kenny, R.A. (2018). 'Cohort Profile Update: The Irish Longitudinal Study on Ageing (TILDA)', Int. J. Epidemiol. 47, 1398-1398l. https://doi.org/10.1093/ije/dyy163

Dudel, C., Schmied, J. (2019). 'Pension adequacy standards: An empirical estimation strategy and results for the United States and Germany', MPIDR Discussion Paper 2019-003. Max Planck Institute for Demographic Research, Munich.

Emmerson, C., Tetlow, G. (2006). 'Further analysis of those at risk of inadequate resources in retirement', Institute for Fiscal Studies, London.

Government of Ireland (2018). A Roadmap for Pensions Reform 2018-2023. Stationery Office, Dublin.

Hurd, M., Rohwedder, S. (2012). 'Economic Preparation for Retirement', in: Investigations in the Economics of Aging. University of Chicago Press, Chicago.

Knoff, M., Been, J., Alessie, R., Caminada, K., Goudswaard, K., Kalwu, A. (2016). 'Measuring retirement savings adequacy: developing a multi-pillar approach in the Netherlands', J. Pension Econ. Finance 15, 55-89. https://doi.org/10.1017/S1474747214000341

Lockwood, Lee M. (2018). "Incidental Bequests and the Choice to Self-Insure Late-Life Risks', American Economic Review, 108 (9): 2513-50.

Mulligan, E., Wijeratne, D., Maher, M. (2019). 'Pensions in Ireland: The Perspectives of Irish Citizens', Whitaker Institute, Galway.

Munnell, A.H., Hou, W., Webb, A. (2015). 'National Retirement Risk Index (NRRI) Update Shows Half of Working-Age Americans Still Falling Short', J. Retire. 3, 34-42. https://doi.org/10.3905/jor.2015.3.2.034

Nivakoski, S. (2014). 'Determinants of Pension Coverage and Retirement Income Replacement Rates - Evidence from TILDA', Econ. Soc. Rev. 45, 299-328.

Nivakoski, S., Barrett, A. (2019). 'Estimating, and Interpreting, Retirement Income Replacement Rates', Econ. Soc. Rev. 50, 587-609.

Nivakoski, S. (2019). 'Does the exchange motive influence intergenerational transfers? Evidence from Ireland', Review of Economics of the Household, 17, 1049-1079. 
Nolan, A., Whelan, A., McGuinness, S., Maitre, B. (2019). 'Gender, Pensions and Income in Retirement' (ESRI Research Series Report No. 87). Economic and Social Research Institute, Dublin.

OECD (2019). Pensions at a Glance: 2019 OECD and G20 Indicators. OECD, Paris.

OECD (2014). OECD Reviews of Pensions Systems: Ireland.

O'Sullivan, V., Nolan, B., Barrett, A., Dooley, C. (2014). 'Income and Wealth in The Irish Longitudinal Study on Ageing', Econ. Soc. Rev. 45, 329-348.

Poterba, J.M. (2015). 'Saver Heterogeneity and the Challenge of Assessing Retirement Saving Adequacy', Natl. Tax J. 68, 377-388.

Poterba, J.M. (2014). 'Retirement Security in an Aging Population', Am. Econ. Rev. 104, 130.

Purcell, P.J. (2012). 'Income Replacement Ratios in the Health and Retirement Study', Soc. Secur. Bull. 72, 37-58.

Redmond, P., McGuinness, S., Kelly, E. (2017). 'Did increasing the state pension age in Ireland affect the retirement rate of 65-year-olds?' QEC Autumn Comment, 1-24.

Sen, A. (1976). 'Poverty: An Ordinal Approach to Measurement', Econometrica, 44(2), 219231. doi:10.2307/1912718

Scholz, J.K., Seshadri, A., Khitatrakun, S. (2006). 'Are Americans Saving "Optimally" for Retirement?' J. Polit. Econ. 114, 607-643. https://doi.org/10.1086/506335

Vincentian Partnership for Social Justice (2019). 'Minimum Essential Standard of Living 2019 Update Report'. Minimum Essential Budget Standards Research Centre, Dublin.

Whelan, B.J., Savva, G.M. (2013). 'Design and Methodology of The Irish Longitudinal Study on Ageing', J. Am. Geriatr. Soc. 61, S265-S268. https://doi.org/10.1111/jgs.12199 



\section{APPENDIX 1: TECHNICAL DETAILS OF SIMULATIONS}

\section{INTRODUCTION}

This appendix describes the data, methodology and key assumptions used to calculate retirement incomes for the cohort of individuals who are due to retire at the SPA between 2022 and 2027. Reflecting the range of benchmarks that can be used to assess retirement income adequacy, and the differing definitions of retirement income, we describe here how the information provided in wave 1 of TILDA is used to calculate a range of key variables. Section 2 outlines the general assumptions and methods underling the analysis, while Sections 3-5 provide more specific details on how the main income components are used to calculate our various benchmarks of adequacy. Section 3 focuses on pre-retirement income, which is necessary for calculating income replacement rates, while Section 4 provides details on the calculation of pension income in retirement. Section 5 describes the calculation of broader definitions of income, incorporating annuitised asset wealth and owner-occupied housing wealth.

\section{GENERAL METHODOLOGY AND MAIN ASSUMPTIONS}

We calculate predicted income and wealth for our cohort of interest at a household level. Our cohort includes all individuals interviewed in TILDA who were born between 1955 and 1960 who have not yet retired, and thus will reach the SPA somewhere between 2022 and 2027. Our unit of analysis is the individual, but our measures of income are primarily at a household level. Therefore, we calculate income for individuals in our cohort while accounting for their spouses or partners. In general, we assume that circumstances (e.g. marital status, employment) do not change between when the individuals are interviewed in the first wave of TILDA (2010) and the time they reach the SPA, at which point they retire. Our aim is to preserve the full sample of individuals covered by the TILDA survey, and therefore we use imputation methods to account for missing values in the data.

Calculations of future disposable income and market income along with private and state pensions are made at an individual level, before being aggregated into a measure of household income. This household income is equivalised using modified OECD equivalence scales, to account for differences in household size. We generate three alternative definitions of household income in retirement. The first definition includes only income from pensions and spouses who may be working, the second includes the annuitised predicted future value of assets, and the third further includes half the annuitised future value of the primary residence. 


\begin{tabular}{l|l|l}
\hline Retirement & \multicolumn{1}{c}{ Assumption } \\
\hline $\begin{array}{l}\text { Lifetime } \\
\text { Future employment }\end{array}$ & $\begin{array}{l}\text { All others retire in the year they reach the state pension age of } 67 . \\
\text { Future DC contributions }\end{array}$ & $\begin{array}{l}\text { Assume employment status remains constant until SPA. } \\
\text { equal to the portion contributed in the month of the survey. }\end{array}$ \\
\hline $\begin{array}{l}\text { Liquidation of assets } \\
\text { Assume individuals liquidate their pension at a fixed annuity rate equal to } 4 \% \\
\text { (source: } \mathrm{CBI} \text { press release). }\end{array}$
\end{tabular}

The goal of the analysis is to determine the adequacy of household disposable income. To do this, we use the TILDA dataset to predict household-level disposable income for each individual in the cohort of interest. Therefore, we must account not only for the personal income of those people in our cohort, but the income of the entire household. We define the household as the member of our cohort plus their spouse or partner. We assume there are no other members in the household. While the TILDA dataset includes information on dependents and other household members on the date of the survey in 2010, this information is likely to be largely irrelevant for family financial circumstance between 2022 and 2027, the years in which the people in our cohort reach the state pension age (SPA). We assume that individuals retire when they reach the SPA, and live until they reach their life expectancy, using sex and age-specific life expectancies from the CSO. We also assume that their status remains constant following the survey until their death, with the exception of retirement.

The primary assumptions regarding past and future behaviour are summarised in Table A1.1, while assumptions made regarding past and future growth rates of economic variables are presented in Table A1.2.

Where possible, we apply realised growth rates and rates of return in order to iterate forward wages and property values. To avoid the composition of asset holdings affecting predicted returns, we follow Crawford and O'Dea (2012) and apply a 2 per cent real rate of return to the holdings of all pension and non-housing assets. ${ }^{27}$ All amounts given in nominal terms are adjusted for inflation. We abstract from heterogeneity in growth rates across the distribution. For forecasts of returns, we abstract from heterogeneities across assets and assume that all assets receive the economy-wide risk-free rate of return. This assumption aligns with standard economic theory; returns in excess of this rate are rewards for bearing risk, and thus are not the focus of this analysis. We express all variables in terms of their 2021 value, using the risk-free rate of interest as our discount factor.

${ }^{27}$ The annualised return on 10-year government bonds is equal to about 2 per cent over this period. 


\begin{tabular}{l|c|c}
\hline \multicolumn{1}{|c|}{ Forecast values } & Assumption & Source \\
\hline $\begin{array}{l}\text { Future real return on assets } \\
\text { Future inflation }\end{array}$ & $2 \%$ per annum & Assumed value \\
\hline $\begin{array}{l}\text { Future nominal wage/disposable } \\
\text { income growth }\end{array}$ & $1.4 \%$ & CBI forecast \\
\hline \multicolumn{1}{|c|}{ Past values } & $4.3 \%$ & CBI forecast \\
\hline $\begin{array}{l}\text { Real return on non-housing assets } \\
\text { Appreciation of second home }\end{array}$ & $\begin{array}{c}\text { Growth in national Residential Property Price } \\
\text { Index (RPPI) for all residential properties }\end{array}$ & CSO \\
\hline Appreciation of primary residence & $\begin{array}{c}\text { Growth in RPPI for all residential properties for } \\
\text { region where dwelling is located }\end{array}$ & CSO \\
\hline Wages (nominal) & Wages assumed to grow in line with average & CSO \\
\hline Disposable income (nominal) & Grows in line with median equivalised disposable & CSO \\
\hline
\end{tabular}

\subsection{Missing value imputation}

A significant portion of responses have missing values. To carry out distributional analysis on the full sample of participants, we use imputation procedures to attach values to missing observations. We use these methods to preserve the full sample throughout the analysis. These procedures are designed to preserve the underlying distribution, with conditional hotdeck being the primary procedure used. This procedure involves assigning each missing value a randomly selected value from the set of known values, conditional on selected characteristics. That is, a random value is assigned to the missing observation from a group of known values with matching selected characteristics. In this way, the conditional distribution of observed values is preserved in the full dataset.

The particular procedure employed for each variable is described below. The selection of characteristics (if any) to condition the random selection is done by considering the specifics of the variable in question. The first constraint involved is sample size. Each time the group is partitioned along a selected characteristic, the pool of known values from which random draws are made is also divided. Therefore, to gain a representative sample, the groups of known values from which our assigned values are drawn should be large relative to the number of missing values, where possible. The goal is to hotdeck from a group of realised values drawn from the same conditional distribution (based on the information we have) as the missing value being imputed.

In the few cases where imputation is not possible due to lack of information - for example, when have no information about the kind of private pension an individual has - we do not hotdeck, but instead assume that the missing value takes zero. 
This assumption allows us to preserve in the analysis the full sample of individuals in our cohort. State non-contributory pension is calculated for all individuals based on predicted income, meaning those with zero predicted income following imputation procedures will receive the full state non-contributory pension.

\section{CALCULATION OF INCOME}

\subsection{Income before retirement}

We use individuals' reported household disposable income to define income before either spouse reaches the SPA. We assume that disposable income grows at the average rate of growth in real disposable income (reported by the CSO) for all people until 2018, the last year of observed data, and grows in line with predicted wage growth thereafter. If a person reports receiving an income from an existing pension at TILDA wave 1, we assume that they will receive this pension for the rest of their life. For households for which disposable income is missing, we hotdeck a value conditional on whether a member of the household is working, the number of people in their household and their region of residence.

For people below the SPA, but who have a spouse who is retired, we assume that their income is given by the income they earn from employment. This seems a reasonable assumption as the Increase for a Qualified Adult (IQA) their spouse would receive should be more lucrative than any other state benefits available to them, and therefore they would not avail of other benefits, which would disqualify them from the IQA. We assume that people not in employment earn zero income from employment, and that income from employment grows at the observed or predicted rate of wage growth (see above). Missing values for pre-retirement earnings are hotdecked conditional on whether the individual is an employee or self-employed. For those who are self-employed as a farmer, we hotdeck values for the various sources of farm income (operating, state payments [REPS], etc) where missing, and aggregate these values. While disposable income accounts for the impact of taxes and transfers, this is not the case for earnings. Therefore, we apply both PRSI and income taxes to market earnings, by applying the stated rules of the present system. We assume that the parameters of the tax system grow at the same rate as average wages.

A number of people in our cohort of interest were not in employment at the time of the survey, but their past salary is needed to calculate their future pension income. To impute monthly salaries for such individuals, we follow Crawford (2012), and use predicted values from a median regression of earnings on age, sex and education level, while accounting for non-linearities in the age profile of wages. This predicted salary level is then used, where necessary, to calculate private pension entitlements. 


\subsection{Income in retirement}

There are three primary sources of income in retirement: supplementary pensions, state contributory pensions, and state non-contributory pensions, along with the aforementioned pension income in receipt at the time of the survey. We use the information contained in the TILDA questionnaire to predict income streams from these three sources, applying various assumptions and imputing missing values where appropriate.

\section{Supplementary pensions}

There are two main types of supplementary pension: defined contribution (DC) and defined benefit (DB). We assume that annual payments from both pensions are uprated in line with wage growth in the years following retirement. Pension income is exempt from PRSI but is still subject to income tax and USC. We account for income tax on all pension income according to the standard rules. Income tax is charged at a household level, so market and pension income of spouses is included in this calculation, where appropriate.

\section{Defined contribution pensions}

Defined contribution (DC) pensions are essentially a savings account that accumulates with personal contributions and returns on assets until the date of retirement, when the holder may purchase an annuity payment from an insurance provider. To calculate defined contribution pensions, we start with the size of each person's fund in 2010, and assume they contribute a fixed portion of their salary to this fund each month. We assume that funds grow at the risk-free real interest rate, abstracting from excess returns. We also assume that contributions occur each month, and interest accrues monthly. This process generates a predicted value of pension fund size at the year of retirement.

We assume that all persons annuitise their pension at a rate of 4 per cent; that is, they sell their fund in exchange for a payment that is equivalent to 4 per cent of the value of their fund annually. Although comprehensive data on annuity rates is not available for Ireland, an inspection by the Central Bank in 2016 suggested that these ranged between 3.8 and 4.5 per cent for a single non-smoking man born in 1950. We test the sensitivity of our results to annuity rates of 3 and 5 per cent, and find that they make no qualitative difference to our main results.

Since calculating the value of a DC scheme involves tracking both a stock and a flow, the imputation procedure we use is more complicated. This procedure is used for individuals who report having a DC pension, but do not report an aspect of it (e.g. value, monthly contribution). To establish the value of the fund at the time of the survey, we hotdeck a value conditional on the type of DC pension (occupational, PRSA, etc). For individuals who do not know the type of DC pension they have, we do not impute and instead assume a contribution rate of zero. 
To impute the value of annual contributions to DC funds, we hotdeck a contribution rate as a portion of monthly salary, again conditional on the type of pension scheme. We then use this assigned contribution rate and the individual's (possibly imputed) monthly salary to obtain their monthly contribution to DC pensions, which we can use to predict their value at the point of retirement. We cap the total contributions made to $\mathrm{DC}$ pensions at 40 per cent of their salary, as this is the agespecific limit of tax exemption allowed by the government immediately before retirement.

\section{Defined benefit pensions}

Defined benefit (DB) schemes provide members with a fixed payment on retirement, equal to some proportion of salary or nominal amount. In terms of contributions, respondents report a monthly payment as a portion of salary or in nominal terms. For those who report a nominal amount, we can directly use this value as the monthly payment they will receive on retirement. For those who report a percentage of salary, we assume that this is calculated as a percentage of salary in the year before retirement. For those with a DB scheme who do not report their future monthly payment, we hotdeck a portion of their salary that they will receive from the full sample of DB payments (including those who report a nominal amount). We then multiply this rate by their (possibly imputed) final salary.

DB schemes are often accompanied by a lump-sum payment received at the point of retirement. For those who report they will receive a lump sum but do not know its amount, we hotdeck a value from the set of known values, including both public and private schemes. A lump sum becomes a stock of cash assets upon its receipt, and therefore we treat it in exactly this manner in calculating pension income. We assume that householders annuitise the value of their lump sum in a similar way to how they annuitise DC funds (described above).

\section{State contributory pensions}

An individual's entitlement to the contributory state pension in Ireland is based on their history of PRSI or social insurance contributions. The rate of pension received is dependent only on the number of contributions, rather than the value of contributions paid.

Until 2018, contributory state pension entitlements were based on the average number of weekly PRSI contributions made by individuals between the time they first entered employment and the time they reached the SPA. Conditional on making contributions before age 56 and having made 520 (10 years') contributions, someone with an average of more than 48 contributions per year was entitled to receive the maximum rate of the contributory state pension. This meant that someone who entered work aged 18, for example, but took time out of the workforce to care for children or parents could end up with a lower entitlement than someone who moved to the country aged 56 and worked for 10 years. 
TABLE A1.3 SIMULATED STATE CONTRIBUTORY PENSION ENTITLEMENTS UNDER DIFFERENT SCHEMES (IN 2019) FOR TILDA COHORT

\begin{tabular}{|c|c|c|c|c|}
\hline & Rate in 2019 & Interim TCA & Old scheme & TCA 40-year \\
\hline & $>=€ 243.40$ & $74.3 \%$ & $67.2 \%$ & $68.2 \%$ \\
\hline & $€ 223.30-€ 243.40$ & $12.1 \%$ & $15.3 \%$ & $7.8 \%$ \\
\hline & $€ 211.40-€ 223.30$ & $4.7 \%$ & $6.1 \%$ & $2.5 \%$ \\
\hline & $€ 161.80-€ 211.40$ & $3.7 \%$ & $1.1 \%$ & $12.4 \%$ \\
\hline & $€ 99.20-€ 161.80$ & $1.8 \%$ & $0.3 \%$ & $4.8 \%$ \\
\hline & $0-€ 99.20$ & $2.5 \%$ & $6.1 \%$ & $1.1 \%$ \\
\hline $\begin{array}{l}\text { Source: } \\
\text { Note: }\end{array}$ & \multicolumn{4}{|c|}{$\begin{array}{l}\text { Authors' calculations using data from the Irish Longitudinal Study of Ageing (TILDA). } \\
\text { Table shows simulated pension entitlement (in } 2019 \text { terms) that we simulate our sample will be entitled to under } \\
\text { the current interim Total Contributions Approach scheme, the historic scheme, and a Total Contributions Approach } \\
\text { scheme if assessed with } 40 \text { years required to obtain a full pension. }\end{array}$} \\
\hline
\end{tabular}

This prompted the Government to propose a change to the pension system whereby entitlements would instead be calculated based on the total number of years a person has been paying PRSI contributions, plus years for which credits were awarded for carrying out caring duties (Government of Ireland, 2018). This Total Contributions Approach (TCA) was due to come into force for all those retiring from late 2020, but full details have yet to be announced, and its introduction appears to have been postponed to $2021 .{ }^{28}$ Those retiring are instead currently assessed on the basis of both the pre-2018 and an 'interim' TCA system, and awarded the larger of the two amounts. ${ }^{29}$

We follow this approach in our simulation of individuals' contributory state pension entitlements, using the information on employment history collected in the first wave of TILDA. This consists of the year in which the individual started working and the number of years spent in employment. We assume that individuals paid the maximum number of contributions in the years they were in work (52), and that their employment status remains unchanged between wave 1 (2010) of the survey and the time they reach the SPA of 67 (between 2022 and 2027).

Individuals can also obtain PRSI credits for time spent caring for children under 12, older family members and for the first year of a spell of unemployment. Since 1994, these have been available to parents caring for children under the age of 12 . From the information provided in the survey we can determine the years for which each individual had a child who was aged under 12 since 1994. For two-adult households, such credits can only be given to one member who has taken time from work to care for children. We assume that the household member with the

\footnotetext{
${ }^{28}$ See https://www.irishtimes.com/business/personal-finance/minister-concedes-state-pension-reform-plansput-back-to-2021-1.4120968

${ }^{29}$ For full details of the way in which contributory state pension entitlements are assessed, see https://www.citizensinformation.ie/en/social_welfare/social_welfare_payments/older_and_retired_people/st ate_pension_contributory.html
} 
least number of years worked is the carer. In situations where both partners have worked the same number of years, we assume that the female spouse is entitled to the credits. ${ }^{30}$ We also assume that parents who have taken time out of work did so when their children were aged under 12; that is, when such time off would have accrued entitlements to credits. Years spent receiving credits are added to years spent in work in order to calculate pension entitlements, along with one year of contributions for those who report a spell of unemployment.

\section{State non-contributory pensions}

Individuals are also potentially eligible to receive a means-tested non-contributory pension. We calculate entitlement to this on the basis of simulated household income and asset holdings in retirement, using the methods described in Section 4 below. Household income is the sum of income from other pensions (state contributory and supplementary) and any earnings from younger spouses or partners still in work. We assume that the parameters governing the calculation of means from assets increase at a rate equal to the real interest rate, while all other parameters of the means test and resultant payments grow in line with wages. ${ }^{31}$

\section{ESTIMATING ASSETS AND PENSION WEALTH}

To reduce household response burden in TILDA, wealth information is collected from only one respondent in each household, the nominated financial respondent. We use the information provided by this financial respondent to generate household-level holdings of wealth and assets. Financial respondents provide point estimates of the value of their assets and outstanding non-mortgage debt. We consider four categories of assets outside of the primary residence: deposits, financial assets, non-primary residences, and other assets. The last category includes land, art, jewellery and business holdings and inheritances. TILDA also includes information on car ownership, though we do not include these or other fast-depreciating consumer durables in our measure of household wealth.

Homeowners also provide a point estimate of the value of their primary residence, which we use to determine the value of the primary residence at the time of the survey. Those who refused or claimed not to know the relevant amount in relation to a wealth question were asked a follow-up question which gave the option of providing a banded answer rather than a point estimate. We use the mid-points of these bands as the values for those who did not answer the original questions. For the remaining missing values, we hotdeck a value of the home, conditional on the range of values. Where homeowners do not provide a banded value, we hotdeck

\footnotetext{
${ }^{30}$ Given that both spouses have equal entitlements, allocating the credits to male or female members has no impact on lifetime household income, but may affect the timing. For example, if spouses retire in different periods, the higher income will be experienced when the female is in retirement according to our assumption. ${ }^{31}$ See https://www.gov.ie/en/publication/66ac9a-operational-guidelines-state-pension-non-contributory/for full details on how entitlement to the non-contributory state pension is assessed.
} 
a value from the full set of houses, conditional on the value being greater than $€ 10,000$, in order to disregard implausibly low values. A similar method is used for the financial assets and other property categories of assets. For deposits, debt and non-primary residences, we unconditionally hotdeck a point estimate of the value of assets.

We assume that the primary residence appreciates in line with the Residential Property Price Index (RPPI) for residences in Dublin or outside Dublin, depending on the location of the home. We also disregard mortgage debt, assuming it will be repaid by the time the state pension age is reached. We assume that secondary residences appreciate in line with the CSO's RPPI for all dwellings. We assume that all other assets and debt earns a real interest rate of $2 \%$ per annum, while further saving (outside of private pension) or repayment of non-mortgage debt does not occur. This is equivalent to calculating individuals' net position (assets less liabilities) excluding secondary residences, and assuming this grows at 2 per cent per year, the method used by Crawford (2012) in a similar study carried out in the UK.

\section{INCOME FROM NET-FINANCIAL ASSETS}

Our broader definitions of income include income derived from drawing down asset holdings in retirement. We assume that this process takes place in an identical manner to DC pension funds; that is, the value of assets is annuitised at a constant rate. However, we assume that income from these sources increases in line with asset values, and thus remains constant in present value terms. Moreover, such payments are not subject to income tax or USC. Since we have no information on the price at which assets were acquired, we cannot apply capital gains tax and thus treat income from assets as exempt from tax. 



\section{APPENDIX 2}

\section{TABLE A2.1 \\ LOGISTIC REGRESSION OF REPLACEMENT RATE INCOME ADEQUACY BENCHMARK (INCLUDING ANNUITISED VALUE OF NET FINANCIAL ASSETS)}

\begin{tabular}{|c|c|c|c|}
\hline & (1) & (2) & (3) \\
\hline Share with income in retirement that is: & $<50 \%$ earnings & $<67 \%$ income & $<80 \%$ income \\
\hline \multicolumn{4}{|l|}{ Living in } \\
\hline \multicolumn{4}{|l|}{ Dublin (reference) } \\
\hline Urban area outside Dublin & 1.084 & $0.721^{*}$ & 0.796 \\
\hline Rural area & $0.621^{*}$ & $0.648^{* *}$ & $0.732^{*}$ \\
\hline \multicolumn{4}{|l|}{ Household type } \\
\hline \multicolumn{4}{|l|}{ Non-farming household (reference) } \\
\hline Farming household & $0.252^{*}$ & $0.339^{* * *}$ & $0.268^{* * *}$ \\
\hline \multicolumn{4}{|l|}{ Cohabitation status in working life } \\
\hline \multicolumn{4}{|l|}{ Married/cohabitating (reference) } \\
\hline Single & $13.902^{* * *}$ & $6.993^{* * *}$ & $5.676^{* * *}$ \\
\hline \multicolumn{4}{|l|}{ Gender } \\
\hline \multicolumn{4}{|l|}{ Man (reference) } \\
\hline Woman & $0.594^{* *}$ & $0.736^{* *}$ & $0.654^{* * *}$ \\
\hline \multicolumn{4}{|l|}{ Education } \\
\hline \multicolumn{4}{|l|}{ Primary or lower (reference) } \\
\hline Lower secondary & 1.998 & $1.495^{*}$ & $1.538^{*}$ \\
\hline Upper secondary & $3.442^{* *}$ & $1.753^{* *}$ & $1.533^{*}$ \\
\hline Post-secondary < degree & $3.056^{* *}$ & $1.691^{* *}$ & $1.547^{*}$ \\
\hline Post-secondary degree or higher & $8.695^{* * *}$ & $2.256^{* * *}$ & $2.119^{* * *}$ \\
\hline Observations & 1904 & 1904 & 1904 \\
\hline
\end{tabular}

Source: Authors' calculations using data from the Irish Longitudinal Study of Ageing (TILDA).

Note: Coefficients show odd-ratios from logistic regressions, interpreted as the likelihood that someone with observed characteristic has equivalised disposable income below the benchmark cut-off compared to the reference category. Stars show statistical significance, indicating a $\mathrm{p}$ value of $<0.05\left({ }^{*}\right),<0.01\left({ }^{* *}\right)$ and $<0.001\left({ }^{* *}\right)$ respectively. Replacement rates are calculated at an individual level comparing equivalised household disposable income in retirement (including annuitised value of financial assets) to equivalised household earnings before retirement, excluding 512 individuals without any earnings (column 1) and equivalised disposable income before retirement (columns 2 and 3 ). 


\begin{tabular}{|c|c|c|c|}
\hline & (1) & (2) & (3) \\
\hline Share with income in retirement that is: & $<50 \%$ earnings & $<67 \%$ income & $<80 \%$ income \\
\hline \multicolumn{4}{|l|}{ Living in } \\
\hline \multicolumn{4}{|l|}{ Dublin (reference) } \\
\hline Urban area outside Dublin & 1.229 & 0.794 & 0.859 \\
\hline Rural area & 0.883 & 0.785 & 0.817 \\
\hline \multicolumn{4}{|l|}{ Household type } \\
\hline \multicolumn{4}{|l|}{ Non-farming household (reference) } \\
\hline Farming household & 0.386 & $0.310^{* * *}$ & $0.261^{* * *}$ \\
\hline \multicolumn{4}{|l|}{ Cohabitation status in working life } \\
\hline \multicolumn{4}{|l|}{ Married/cohabitating (reference) } \\
\hline Single & $10.466^{* * *}$ & $4.973^{* * *}$ & $4.354^{* * *}$ \\
\hline \multicolumn{4}{|l|}{ Gender } \\
\hline \multicolumn{4}{|l|}{ Man (reference) } \\
\hline Woman & $0.620^{*}$ & $0.680^{* * *}$ & $0.629^{* * *}$ \\
\hline \multicolumn{4}{|l|}{ Education } \\
\hline \multicolumn{4}{|l|}{ Primary or lower (reference) } \\
\hline Lower secondary & 1.751 & 1.275 & 1.378 \\
\hline Upper secondary & $3.502^{*}$ & 1.230 & 1.339 \\
\hline Post-secondary < degree & $3.703^{* *}$ & 1.373 & 1.396 \\
\hline Post-secondary degree or higher & $8.867^{* * *}$ & $1.716^{* *}$ & $1.759^{* *}$ \\
\hline Observations & 1904 & 1904 & 1904 \\
\hline
\end{tabular}

Source: Authors' calculations using data from the Irish Longitudinal Study of Ageing (TILDA).

Note: Coefficients show odd-ratios from logistic regressions, interpreted as the likelihood that someone with observed characteristic has equivalised disposable income below the benchmark cut-off compared to the reference category. Stars show statistical significance, indicating a $\mathrm{p}$ value of $<0.05(*),<0.01(* *)$ and $<0.001(* * *)$ respectively. Replacement rates are calculated at an individual level comparing equivalised household disposable income in retirement (including annuitised value of net financial assets and half annuitised value of primary residence) to equivalised household earnings before retirement, excluding 512 individuals without any earnings (column 1) and equivalised disposable income before retirement (columns 2 and 3 ). 
TABLE A2.3 LOGISTIC REGRESSION OF POVERTY-LINE RATE INCOME ADEQUACY BENCHMARK (INCLUDING ANNUITISED VALUE OF NET FINANCIAL ASSETS)

\begin{tabular}{|c|c|c|c|}
\hline & (1) & (2) & (3) \\
\hline Share with income in retirement that is: & $<60 \%$ median & $<50 \%$ median & $<$ MESL \\
\hline \multicolumn{4}{|l|}{ Living in } \\
\hline \multicolumn{4}{|l|}{ Dublin (reference) } \\
\hline Urban area outside Dublin & 0.954 & 0.555 & 0.672 \\
\hline Rural area & 1.005 & 1.251 & $28.603^{* * *}$ \\
\hline \multicolumn{4}{|l|}{ Household type } \\
\hline \multicolumn{4}{|l|}{ Non-farming household (reference) } \\
\hline Farming household & 0.502 & 0.234 & $0.437^{*}$ \\
\hline \multicolumn{4}{|l|}{ Cohabitation status in working life } \\
\hline \multicolumn{4}{|l|}{ Married/cohabitating (reference) } \\
\hline Single & 0.891 & $0.544^{*}$ & $32.676^{* * *}$ \\
\hline \multicolumn{4}{|l|}{ Gender } \\
\hline \multicolumn{4}{|l|}{ Man (reference) } \\
\hline Woman & $1.531^{*}$ & $2.591^{* *}$ & $2.038^{* * *}$ \\
\hline \multicolumn{4}{|l|}{ Education } \\
\hline \multicolumn{4}{|l|}{ Primary or lower (reference) } \\
\hline Lower secondary & 0.779 & 0.603 & 0.782 \\
\hline Upper secondary & $0.595^{*}$ & 0.463 & 0.652 \\
\hline Post-secondary < degree & $0.438^{* *}$ & 0.663 & $0.471^{* *}$ \\
\hline Post-secondary degree or higher & $0.287^{* * *}$ & $0.165^{* *}$ & $0.303^{* * *}$ \\
\hline Observations & 1904 & 1904 & 1904 \\
\hline
\end{tabular}

Source: Authors' calculations using data from the Irish Longitudinal Study of Ageing (TILDA).

Note: Coefficients show odd-ratios from logistic regressions, interpreted as the likelihood that someone with observed characteristic has equivalised disposable income below the benchmark cut-off compared to the reference category. Stars show statistical significance, indicating a p value of $<0.05(*),<0.01\left({ }^{* *}\right)$ and $<0.001(* * *)$ respectively. 
TABLE A2.4 LOGISTIC REGRESSION OF POVERTY-LINE INCOME ADEQUACY BENCHMARK (INCLUDING ANNUITISED VALUE OF NET FINANCIAL ASSETS PLUS HALF VALUE OF PRIMARY RESIDENCE)

\begin{tabular}{|c|c|c|c|}
\hline & (1) & (2) & (3) \\
\hline Share with income in retirement that is: & $<60 \%$ median & $<50 \%$ median & $<$ MESL \\
\hline \multicolumn{4}{|l|}{ Living in } \\
\hline \multicolumn{4}{|l|}{ Dublin (reference) } \\
\hline Urban area outside Dublin & 0.948 & 0.669 & 0.698 \\
\hline Rural area & 1.182 & 1.333 & $8.562^{* * *}$ \\
\hline \multicolumn{4}{|l|}{ Household type } \\
\hline \multicolumn{4}{|l|}{ Non-farming household (reference) } \\
\hline Farming household & 0.656 & 0.323 & 0.587 \\
\hline \multicolumn{4}{|l|}{ Cohabitation status in working life } \\
\hline \multicolumn{4}{|l|}{ Married/cohabitating (reference) } \\
\hline Single & $0.654^{*}$ & $0.495^{*}$ & $6.902^{* * *}$ \\
\hline \multicolumn{4}{|l|}{ Gender } \\
\hline \multicolumn{4}{|l|}{ Man (reference) } \\
\hline Woman & 1.477 & $2.232^{*}$ & 1.435 \\
\hline \multicolumn{4}{|l|}{ Education } \\
\hline \multicolumn{4}{|l|}{ Primary or lower (reference) } \\
\hline Lower secondary & 0.623 & 0.725 & 0.727 \\
\hline Upper secondary & $0.425^{* *}$ & 0.374 & $0.431^{* *}$ \\
\hline Post-secondary < degree & $0.382^{* *}$ & 0.804 & $0.525^{*}$ \\
\hline Post-secondary degree or higher & $0.186^{* * *}$ & $0.083^{*}$ & $0.202^{* * *}$ \\
\hline Observations & 1904 & 1904 & 1904 \\
\hline
\end{tabular}

Source: Authors' calculations using data from the Irish Longitudinal Study of Ageing (TILDA).

Note: Coefficients show odd-ratios from logistic regressions, interpreted as the likelihood that someone with observed characteristic has equivalised disposable income below the benchmark cut-off compared to the reference category. Stars show statistical significance, indicating a p value of $<0.05\left({ }^{*}\right),<0.01\left(^{* *}\right)$ and $<0.001\left(*^{* *}\right)$ respectively. 
Whitaker Square,

Sir John Rogerson's Quay, Dublin 2

Telephone +35318632000

Email admin@esri.ie

Web www.esri.ie

Twitter @ESRIDublin

ISBN 978-0-7070-0530-0 